\title{
Methodology for implementing power plant efficiency standards for power generation: potential emission reduction
}

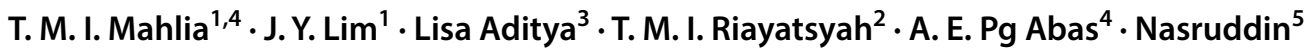

Received: 13 August 2017 / Accepted: 5 December 2017 / Published online: 13 December 2017

(c) The Author(s) 2017. This article is an open access publication

\begin{abstract}
Some methods of generating power such as power generation through coal, natural gas, oil result in inevitable emissions of greenhouse gases. While power generation is necessary due to its increasing demand, it is important for power companies to generate their power in an efficient manner to reduce its effect on the environment. One of the most effective ways of tackling inefficiency issues is through the implementation of efficiency standard. While there exist a lot of studies addressing the topic of energy efficiency standards, there are very few papers that deal specifically with efficiency standard for power generation plant. This paper presents methodology for the implementation of power plant efficiency standard; as mandatory or voluntary regulatory instrument, that may be implemented by the government to control greenhouse emissions from power plants. It is hoped that through its implementation, power companies shall become more conscious of their efficiency and emission quality, hereby encouraging the adoption of more efficient energy sources and latest available technologies. In this paper, methods of calculating greenhouse intensity value and its corresponding allowable ranges have been demonstrated. Case study on a 10-year-old base-load multi-fuel-fired power plant in Malaysia has shown that the power plant is in conformance to the power plant efficiency standard, with an actual greenhouse intensity of $859.4461 \mathrm{kgCO}_{2} / \mathrm{MWh}$ sent-out, well within the allowable range of greenhouse intensities for that power plant which is between 760 and $890 \mathrm{kgCO} / \mathrm{MWh}_{2}$ sent-out. It has also been demonstrated that older power plants are allowed to have higher values of greenhouse intensity. Benefits of utilising natural gas and operating the power plant at full load have also been shown.
\end{abstract}

Keywords Techno-economic $\cdot$ Energy efficiency standard $\cdot$ Power generation $\cdot$ Life cycle cost

\section{List of symbols}

$A$

$A_{\mathrm{ar}}$

Rate of fuel burnt (kg) by the power plant

Percentage of ash in fuel, as received or as fired $(\%)$

Lisa Aditya

lisaadityamawardi@gmail.com

1 Department of Mechanical Engineering, College of Engineering, Universiti Tenaga Nasional, 43000 Kajang,

Selangor, Malaysia

2 Department of Mechanical Engineering, Faculty of Engineering, University of Malaya, 50603 Kuala Lumpur, Malaysia

3 Department of Environmental Engineering, Gdańsk University of Technology, 80-233 Gdańsk, Poland

4 Faculty of Integrated Technologies, Universiti Brunei Darussalam, Jalan Tungku Link, Gadong 1410, Brunei Darussalam

5 Department of Mechanical Engineering, University of Indonesia, Depok 16424, Indonesia
AFBC Atmospheric fluidised bed combustor

$C_{\text {ar }}$ Percentage of carbon in fuel, as received or as fired (\%)

$C_{\mathrm{a}} \quad$ Mass percentage (\%) of carbon from fuel as received, as sampled or as fired

$C_{\text {ash }}$

CCS

GHG

$\mathrm{CH}_{4}$

$\mathrm{CO}_{2}$

IGCC

$e_{\text {allo. }}$

$E_{\mathrm{A}}$

$E_{\mathrm{G}}$

$E_{\text {so }}$ Percentage of carbon in ash, as sampled (\%) Carbon capture and storage Greenhouse gases

Methane gas Carbon dioxide gas Integrated gasification combined cycle Maximum error allowance due to fuel sampling and quantity metering (\%) Energy consumed by the auxiliary loads over time period $T$ Energy generated at the generator terminals over time period $T$ Total energy sent out by the power plant in MWh sent out over time period $T$ 


\begin{tabular}{|c|c|}
\hline $\mathrm{EF}_{j}$ & $\begin{array}{l}\text { Total emission of greenhouse gas } j \text { produced } \\
(\mathrm{kg}) \text { by the power plant }\end{array}$ \\
\hline ER & $\begin{array}{l}\text { Overall emission reduction efficiency of the } \\
\text { power plant }\end{array}$ \\
\hline $\mathrm{EM}_{\mathrm{CO}_{2} \text {, equiv. }}$ & $\begin{array}{l}\text { Total emission for carbon dioxide equiva- } \\
\text { lence, from the power plant in } \mathrm{kgCO}_{2} \text { equiv } \\
\text { over time period } T\end{array}$ \\
\hline$F_{j}$ & $\begin{array}{l}\text { Emission factors for greenhouse gas } j \text { by the } \\
\text { power plant }\left(\mathrm{kg} \mathrm{CO}_{2} / \mathrm{kg} \text { fuel }\right)\end{array}$ \\
\hline$F_{\mathrm{CO}_{2}}$ & $\begin{array}{l}\text { Emission factors for greenhouse gas } \mathrm{CO}_{2} \text { by } \\
\text { the power plant }\left(\mathrm{kg} \mathrm{CO}_{2} / \mathrm{kg} \text { fuel }\right)\end{array}$ \\
\hline$F_{\mathrm{CO}_{2} \text { equiv }, i}$ & $\begin{array}{l}\text { Collective emission factor, in carbon dioxide } \\
\text { equivalence by the power plant from fuel } i \\
\left(\mathrm{~kg} \mathrm{CO}_{2} / \mathrm{kg} \text { fuel }\right)\end{array}$ \\
\hline$F_{\mathrm{CO}_{2}, i}$ & $\begin{array}{l}\text { Emission factors for } \mathrm{CO}_{2} \text { by the power plant } \\
\text { from fuel } i\left(\mathrm{~kg} \mathrm{CO}_{2} / \mathrm{kg} \text { fuel }\right)\end{array}$ \\
\hline$F_{\mathrm{CH}_{4}, i}$ & $\begin{array}{l}\text { Emission factors for } \mathrm{CH}_{4} \text { by the power plant } \\
\text { from fuel } i\left(\mathrm{~kg} \mathrm{CO}_{2} / \mathrm{kg} \text { fuel }\right)\end{array}$ \\
\hline$F_{\mathrm{N}_{2} \mathrm{O}, i}$ & $\begin{array}{l}\text { Emission factors for } \mathrm{N}_{2} \mathrm{O} \text { by the power plant } \\
\text { from fuel } i\left(\mathrm{~kg} \mathrm{CO}_{2} / \mathrm{kg} \text { fuel }\right)\end{array}$ \\
\hline GHR & Generated heat rate of the power plant \\
\hline GI & $\begin{array}{l}\text { Greenhouse intensity value }\left(\mathrm{kg} \mathrm{CO}_{2} / \mathrm{MWh}\right. \\
\text { sent-out) }\end{array}$ \\
\hline $\mathrm{GI}_{\mathrm{R}}$ & $\begin{array}{l}\text { Greenhouse intensity reference value (kg } \\
\mathrm{CO}_{2} / \mathrm{MWh} \text { sent-out) }\end{array}$ \\
\hline $\mathrm{GI}_{\text {Lower }}$ & $\begin{array}{l}\text { Reference lower greenhouse intensity value } \\
\text { (kg CO} / \mathrm{MWh} \text { sent-out) }\end{array}$ \\
\hline $\mathrm{GI}_{\text {Upper }}$ & $\begin{array}{l}\text { Reference upper greenhouse intensity value } \\
\text { ( } \mathrm{kg} \mathrm{CO}_{2} / \mathrm{MWh} \text { sent-out) }\end{array}$ \\
\hline GWP & Global warming potential \\
\hline $\mathrm{HCF}$ & Hyrdofluorocarbons gas \\
\hline$L$ & Output factor or load of the power plant \\
\hline$m_{i}$ & $\begin{array}{l}\text { Total mass of fuel } i \text { by the power plant in } \mathrm{kg} \\
\text { over time period } T\end{array}$ \\
\hline$m_{\mathrm{CO}_{2} \text {, equiv. }}$ & $\begin{array}{l}\text { Carbon dioxide equivalence's quantity from } \\
\text { the three different emission gases (tonne) }\end{array}$ \\
\hline$m_{\mathrm{CO}_{2}}$ & Emission quantity of $\mathrm{CO}_{2}$ (tonne) \\
\hline$m_{\mathrm{CH}_{4}}$ & Emission quantity of $\mathrm{CH}_{4}$ (tonne) \\
\hline$m_{\mathrm{N}_{2} \mathrm{O}}$ & Emission quantity of $\mathrm{N}_{2} \mathrm{O}$ (tonne) \\
\hline$N$ & $\begin{array}{l}\text { Number of the different sources of fuel uti- } \\
\text { lised by the power plant }\end{array}$ \\
\hline $\mathrm{N}_{2} \mathrm{O}$ & Nitrous oxide gas \\
\hline$P_{\mathrm{I}}$ & $\begin{array}{l}\text { Total installed capacity of the power plant } \\
\text { (MWh) }\end{array}$ \\
\hline PFBC & Pressurised fluidised bed combustor \\
\hline PFC & Perfluorcarbons gas \\
\hline$Q_{i}$ & $\begin{array}{l}\text { Gross calorific value of fuel } i \text { at constant } \\
\text { pressure, as fired }(\mathrm{MJ} / \mathrm{kg})\end{array}$ \\
\hline $\mathrm{SF}_{6}$ & Sulphur-hexafluoride gas \\
\hline SHR & Sent-out heat rate of the power plant \\
\hline$Y$ & $\begin{array}{l}\text { Power plant age (since new or refurbished) } \\
\text { (year) }\end{array}$ \\
\hline
\end{tabular}

$\eta_{\mathrm{GEN}} \quad$ Generation thermal efficiency (\%) of the power plant

$\eta_{\text {so }} \quad$ Sent-out thermal efficiency (\%) of the power plant

$\eta_{\text {so,ref }} \quad$ Reference sent-out thermal efficiency (\%) of the power plant

\section{Introduction}

Climate change may be considered one of the most pressing problems that the world is facing. The use of fossil fuel for power generation releases greenhouse gases and, consequently, has caused many negative effects on the environment. Rising temperature and rising sea-level are just some of the environmental phenomena attributed to our reliance on fossil fuel. Another problem associated with climate change is the depletion of fossil fuel. Over-usage of fossil fuel, albeit for useful and necessary purposes, not only leads to our current environmental predicament but also to the depletion of scarce fossil resources that may be extracted from the core of the earth.

A lot of researches have been done to explore alternative energy sources which are kinder to the environment and do not rely on fossil fuel. Among them is the use of photovoltaic (PV) technology to convert solar energy onto electrical energy, especially popular in the tropical regions with high solar irradiation (Kabir et al. 2018). Other methods (Ali et al. 2012; Pioro et al. 2016) are power generation from biomass (Demirbas 2009, 2010), solid biofuel such as oil extraction from Jatropha Curcas L. (Mardoyan and Braun 2015), hydro (Manzano-Agugliaro et al. 2017), wind (Zerrahn 2017), nuclear (Pioro and Duffey 2015).

Although the use of these alternative sources of energy is increasing, their adoption is not without challenges. Most of the methods and products used to generate power from these sources are relatively new, making power generation industry wary and more cautious in adopting the technologies. Other possible barriers are financial, regulatory and information barriers (Ali et al. 2012) and also the demand of an up-to-date technology with high acquisition and as well as management with a variable cost to create new concept of urban green management (Maroušek et al. 2014). Energy stored in fossil fuels are also significantly greater than in any other currently available sources; there is no other equivalently cheap, powerful and safe energy available, from nuclear energy, solar power, wind power, hydrogen or biomass. Due to these, fossil fuel continues to contribute to a large chunk of the energy sources that are used by power generation industry worldwide for their power generation needs (World Energy Resources 2016).

It is accepted that fossil fuel remains and shall continue to be used for the foreseeable future (World Energy 
Resources 2016) by power plants around the world; and together with it, the environmental impact and the depletion of scarce resources that comes from its usage. However, steps must be taken to reduce its impact.

One of the ways of reducing the environmental impact of power plants is through the implementation of Power Plant Efficiency Standard. The ultimate goal of Power Plant Efficiency Standard is to improve efficiency in energy generation as well as to reduce greenhouse emission, through adherence to the standard of best practices (Rahman et al. 2015; Saidur and Mahlia 2010). Although energy efficiency standards were first established about four decades ago, relatively very little information on Power Plant Efficiency Standard has been published on its theory and methodology. Some essential information is presented in references (Augustus de Melo and de Martino Jannuzzi 2010; de Alencar Medeiros Filho et al. 1999; Mahlia et al. 2002).

The use of efficiency standard to improve efficiency and to reduce the negative impact caused from power plant is not something novel. United States Environment Protection Agency (EPA) proposed a comprehensive carbon pollution standard, called clean power plan (Agency 2015), a regulatory standard in order to cut down greenhouse pollution from the thousands of power plants in the USA. The plan is a part of climate action plan initiated by US President Barack Obama in 2013 and is still currently in the proposal stage. According to research, Clean Power Plan is able to cut down $30 \%$ of carbon emission from the power sector. Considering that the US power sector is responsible for almost one-third of the US greenhouse emissions, the standard is expected to cut down carbon dioxide emission by a whopping amount of 5344 million metric tons in 15 years; and to increase national public health and climate benefits from US\$55 billion to US\$93 billion (NRDC Summary of EPA's Clean Power Plan, Carbon Pollution Standards for Existing Power Plants 2014).

In Australia, the government came out with a new energy efficiency standard, called generator efficiency standard (GES) (Office 2000b). GES acts as a regulatory instrument to control greenhouse emissions from power plants, covering all types of power plants which are running on different types of fossil fuels including coal, gas and oil, with audit or review at least once every 5 years to ensure good performance in greenhouse efficiency as well as penalty for non-compliance power plants participating in the standards. Emission efficiency standard (tonnes of $\mathrm{CO}_{2}$ eq/ MWh sent out) is used for the evaluation of power plant efficiency in GES. Four mega tonnes of $\mathrm{CO}_{2}$ is targeted to be saved through implementation of the standard (Office 2000a), requiring AU $\$ 10$ to save a tonne of $\mathrm{CO}_{2}$ released. Despite its huge cost, average payback period of the project is projected to be approximately 8 years or even less.
In this paper, implementation aspect of power plant efficiency standard shall be discussed. Particularly, methodology for the calculation of greenhouse intensity value, a measure used in the standard, shall be demonstrated by using performance data from old power plants in Malaysia.

Power generation industry in Malaysia is one of the most advanced and reliable power generation industries in the South East Asian region, with no incident of major blackout recorded in the country since the year 1996 (Archives 2005). However, like other countries with high-population growth, the country experienced rapid increase in electricity demand. The future sales, demand and generation load forecasted by the Energy Commission of Malaysia are tabulated in Table 1 (Energy Commission 2013).

Due to this, Malaysian power grid system is currently facing a decline in its electricity generation reserve margin, with reserve margin going down from $40 \%$ in the year 2010 to around 25\% recorded recently (Pandey 2014), necessitating constructions of new power plants to satisfy the surge of electricity demand. Future generation development plan based on the Energy Commission of Malaysia data is presented in Table 2 (Energy Commission 2014).

Constructions of power plants in Malaysia are unavoidable to quench the thirst for high demand of electricity; however, a lot of ways may be implemented to reduce its impact on the environment, with the implementation of power plant efficiency standard being one of them. It is noted that power plant efficiency standard for power generation is yet to be implemented in Malaysia.

Continual usage of fossil fuel and increasing number of power plants with no existing standard in place makes Malaysia a nice case study to explore the possibility of power plant efficiency standard in handling inefficient power plants and their emissions, in terms of its implementation, techno-economic analysis, etc. Although the case study in this paper specifies power plant in Malaysia, it is directly applicable to other power plants internationally with minor modifications.

The ultimate aim of power plant energy efficiency standard is to compare the actual greenhouse emission produced by a given power plant against the allowable greenhouse emissions by power plant of a specific type. If the power plant's greenhouse emission falls within the allowable range, the plant is said to be in compliance with the power plant energy efficiency standard. As such, the process of determining the power plant energy efficiency is composed of two distinct steps:

- to determine the average greenhouse emission of the power plant

- to determine the range of greenhouse emission for power plant of a specific type, depending on the type of fuels that the power plant uses, its age, etc. 
Table 1 Power generation and demand forecast in Malaysia

\begin{tabular}{llllllll}
\hline & Year & Sales $(\mathrm{GWh})$ & Growth $(\%)$ & Generation $(\mathrm{GWh})$ & Growth $(\%)$ & $\begin{array}{l}\text { Peak } \\
\text { demand } \\
(\mathrm{MW})\end{array}$ & Growth (\%) \\
\hline Historical & & & & & & & \\
& 2003 & 64,292 & 7.1 & 73,795 & 7.1 & 11,329 & 5.1 \\
& 2004 & 68,963 & 7.3 & 79,022 & 7.1 & 12,023 & 6.1 \\
& 2005 & 73,103 & 6.0 & 83,303 & 5.4 & 12,493 & 3.9 \\
& 2006 & 75,446 & 3.2 & 86,472 & 3.8 & 12,990 & 4.0 \\
& 2007 & 79,575 & 5.5 & 90,283 & 4.4 & 13,620 & 4.8 \\
& 2008 & 84,464 & 6.1 & 94,370 & 4.5 & 14,007 & 2.8 \\
& 2009 & 82,276 & -2.6 & 92,623 & -1.9 & 14,245 & 1.7 \\
& 2010 & 89,533 & 8.8 & 100,991 & 9.0 & 15,072 & 5.8 \\
& 2011 & 92,291 & 3.1 & 103,354 & 2.3 & 15,476 & 2.7 \\
& 2012 & 96,257 & 4.3 & 106,884 & 3.4 & 15,826 & 2.3 \\
& 2013 & 100,135 & 4.0 & 110,617 & 3.5 & 16,539 & 4.5 \\
& 2014 & 104,303 & 4.2 & 114,689 & 3.7 & 17,131 & 3.6 \\
Forecast & 2015 & 108,167 & 3.7 & 118,420 & 3.3 & 17,671 & 3.2 \\
& 2016 & 112,586 & 4.1 & 123,049 & 3.9 & 18,338 & 3.8 \\
& 2017 & 116,540 & 3.5 & 127,160 & 3.3 & 18,926 & 3.2 \\
& 2018 & 120,780 & 3.6 & 131,573 & 3.5 & 19,558 & 3.3 \\
\hline
\end{tabular}

Table 2 New generation development project

\begin{tabular}{lllll}
\hline No. & Projects & Fuel & Capacity (MW) & Commercial operation date \\
\hline 1 & TNB Janamanjung (Unit 4) & Coal & 1010 & 31 Mar 2015 \\
2 & CBPS redevelopment & Gas & 384.7 & 1 Sept 2015 \\
3 & Hulu Terengganu & Hydro & 250 & U1:16th Sept 2015 \\
& & & & U2:17th Dec 2015 \\
4 & Ulu Jelai & Hydro & 372 & U1:13th Dec 2015 \\
& & & & U2:14th Mar 2016 \\
5 & TNB Prai & Gas & 1071.43 & 1 st Jan 2016 \\
6 & Tg. Bin energy & Coal & 1000 & 1 st Mar 2016 \\
7 & Hulu Terengganu (Tembat) & Hydro & 15 & U1: 15th Nov 2016 \\
& & & & U2: 15th Dec 2016 \\
8 & Pengerang co-generation & Gas & 400 & 1 st June 2017 \\
9 & TNB Manjung five & Coal & 1000 & 1 st Oct 2017 \\
10 & New CCGT & Gas & 1000 & 1 st June 2018 \\
11 & Jimah east power & Coal & 1000 & U1: 15th Nov 2018 \\
& & & 1000 & U2: 15th May 2019 \\
12 & Additional Chenderoh & Hydro & 12 & Oct 2018 \\
13 & Tekai & Hydro & 156 & Dec 2020 \\
14 & Telom & Hydro & 132 & Dec 2022 \\
\hline
\end{tabular}

Power plant efficiency standard outlines different procedures for new power plant and existing/refurbished power plants participating in the standard. Ardent readers are encouraged to refer to the appendix for descriptions of the adopted standard in this paper.

The structure for the rest of this paper is as follows. "Greenhouse emission" section provides general information on different greenhouse gases that are emitted and their amount, from different types of power plant. Consequently, methods of calculating greenhouse emission and its range of allowable emission for subsequent years are outlined. Real performance data of old power plants in Malaysia shall be used to determine its greenhouse emission and range of allowable emission, the result can be seen in section "Results and discussion". The last section outlines the conclusion of this paper. 


\section{Greenhouse emission}

Greenhouse emissions produced from power plants are measured by its greenhouse intensity (GI) value, which is the ratio of the environmental impact from energy generation to the energy generated by the power plant. GI value is commonly expressed in $\mathrm{kgCO}_{2} / \mathrm{MWh}$, carbon dioxide gas sent out by the power plant per unit of energy produced.

\section{Greenhouse gases}

Carbon dioxide is not the only greenhouse gases that are of concern to the policy-makers and environmentalists. In fact, greenhouse emission is associated with most greenhouse gases, i.e. gases which are capable of absorbing and emitting radiation at specific wavelengths similar to thermal infrared radiation in the atmosphere. These include carbon dioxide $\left(\mathrm{CO}_{2}\right)$, methane $\left(\mathrm{CH}_{4}\right)$, nitrous oxide $\left(\mathrm{N}_{2} \mathrm{O}\right)$, hydrofluorocarbons (HFCs), perfluorocarbons (PFCs) and sulphur hexafluoride $\left(\mathrm{SF}_{6}\right)$, gases produced from the burning of fossil fuels.

Majority of greenhouse gases are also associated with power plant gas emissions, and hence, it is important to consider them in the power plant energy efficiency standard: most importantly, carbon dioxide $\left(\mathrm{CO}_{2}\right)$, methane $\left(\mathrm{CH}_{4}\right)$ and nitrous oxide $\left(\mathrm{N}_{2} \mathrm{O}\right)$ (Agency 2014). In Table 3, it is shown that all three gases are emitted by the three types of power plants considered in this paper: coal, diesel oil and natural gas power plants, and thus, these three gases must be included in calculating the environmental impact from power plant.

As the unit of measurement of greenhouse intensity is in terms of carbon dioxide, the other two greenhouse gases, i.e. methane and nitrous oxide, need to be first converted to their carbon dioxide equivalence. Equation (1) gives the conversion formula to determine the corresponding carbon dioxide equivalence from the three major greenhouse emissions (Bernstein 2007):

$m_{\mathrm{CO}_{2} \text {,equiv. }}=m_{\mathrm{CO}_{2}}+21 \times m_{\mathrm{CH}_{4}}+310 \times m_{\mathrm{N}_{2} \mathrm{O}}$

The three factor of values 1,21 and 310 used in the conversion equation are the global warming potential (GWP) of $\mathrm{CO}_{2}, \mathrm{CH}_{4}$ and $\mathrm{N}_{2} \mathrm{O}$, respectively (Ranganathan 2004). These

Table 3 Greenhouse gases considered in the implementation of power plant energy efficiency standard, showing the different gases applicable to the different type of power plant as well as the global warming potential of each greenhouse gas

\begin{tabular}{lclll}
\hline $\begin{array}{l}\text { Greenhouse } \\
\text { gases }\end{array}$ & $\begin{array}{l}\text { Global warming } \\
\text { potential }\end{array}$ & \multicolumn{4}{l}{ Applicability } \\
\cline { 3 - 5 } \cline { 3 - 5 } & 1 & Coal & Oil & Gas \\
\hline $\mathrm{CO}_{2}$ & 21 & $\checkmark$ & $\checkmark$ & $\checkmark$ \\
$\mathrm{CH}_{4}$ & 310 & $\checkmark$ & $\checkmark$ & $\checkmark$ \\
$\mathrm{N}_{2} \mathrm{O}$ & $\checkmark$ & $\checkmark$ & $\checkmark$ \\
\hline
\end{tabular}

values signify the potential harm caused by one unit of $\mathrm{CH}_{4}$ in the atmosphere which is equivalent to the potential harm caused by 21 units of $\mathrm{CO}_{2}$. Similarly, the potential harm caused by one unit of $\mathrm{N}_{2} \mathrm{O}$ is equivalent to 310 units of $\mathrm{CO}_{2}$.

\section{Emission factors}

Emission factor relates the amount of greenhouse gas produced and absorbed by the atmosphere with an activity associated with the production of that greenhouse gas (Agency 1995). With unit (kg of greenhouse gas produced)/kg of fuel used, it signifies the amount of greenhouse gas emission that is produced in kilograms by burning one kilogram of fuel. Consequently, emission factor is normally used to estimate the amount of greenhouse emission that is produced by a power plant. General emission estimation formula for a particular plant type is given by:

$\mathrm{EF}_{j}=A \times F_{j} \times\left(1-\frac{\mathrm{ER}}{100}\right)$

Index $j$ represents the different greenhouse gases considered. As seen from the above formula, the emission of greenhouse gas $j$ is dependent on the amount of fuel burnt (activity rate of the power plant), the emission reduction efficiency of the power plant and also, the emission factor of the power plant itself.

Emission factor $F_{j}$ is dependent on the source of fuel utilised by the power plant: either natural gas, diesel oil or coal. Also, for a given source of fuel, emission factors of different greenhouse gases, carbon dioxide, methane and nitrous oxide, are different and are based on their compositions within the source of fuel.

\section{Gas-fired power plant}

Emission factor of carbon dioxide $\left(\mathrm{CO}_{2}\right)$ from combustion of fuel in a gas-fired power generation plant may be calculated using fuel gas composition of the plant. Sample calculation of $\mathrm{CO}_{2}$ emission factor for natural gas is given in Table 4 (Australian Government 2014).

However, emission factors of methane $\left(\mathrm{CH}_{4}\right)$ and nitrous oxide $\left(\mathrm{N}_{2} \mathrm{O}\right)$ cannot be calculated from the fuel gas composition. This is because both methane and nitrous oxide are not significantly produced from normal combustion of natural gas; rather, methane is emitted as a result of incomplete combustion and nitrous oxide is emitted under low temperature, in both of which the plant operator seeks to avoid. As such, emission factors of methane and nitrous oxide are normally obtained through a program of regular sampling and analysis, or through estimation. Table 5 gives common emission factors of methane and nitrous oxide, for different technologies employed in gas-fired power plant. 
Table 4 Sample calculation of $\mathrm{CO}_{2}$ emission factor for natural gas

\begin{tabular}{|c|c|c|c|c|c|c|c|}
\hline & Component & \multirow{3}{*}{$\begin{array}{l}\text { Mole\% (or vol.\%) } \\
a\end{array}$} & \multirow{3}{*}{$\begin{array}{l}\text { Molecular } \\
\text { weight } \mathrm{kg} / \mathrm{kmole} \\
b\end{array}$} & \multicolumn{2}{|c|}{ Density $\mathrm{Kg} / \mathrm{m}^{3}$} & \multirow{3}{*}{$\begin{array}{l}\text { Mass } \% \\
e \\
d * 100 / d_{\text {total }}\end{array}$} & \multirow{3}{*}{$\begin{array}{l}\mathrm{Kg} \mathrm{CO}_{2} / \mathrm{kg} \text { fuel } \\
F \\
44.01 * e /(b * 100)\end{array}$} \\
\hline & & & & $c$ & $d$ & & \\
\hline & & & & $b / V$ & $a * c$ & & \\
\hline Methane & $\mathrm{CH}_{4}$ & 94.000 & 16.043 & 0.678903 & 63.8169 & 87.9678 & 2.4126 \\
\hline Ethane & $\mathrm{C}_{2} \mathrm{H}_{6}$ & 0.200 & 30.07 & 1.272493 & 0.25450 & 0.3508 & 0.0103 \\
\hline Propane & $\mathrm{C}_{3} \mathrm{H}_{8}$ & 0.150 & 44.097 & 1.866084 & 0.27991 & 0.3858 & 0.0155 \\
\hline Butane & $\mathrm{C}_{4} \mathrm{H}_{10}$ & 0.005 & 58.123 & 2.459632 & 0.01230 & 0.0170 & 0.0051 \\
\hline Pentane & $\mathrm{C}_{5} \mathrm{H}_{12}$ & 0.003 & 72.15 & 3.053223 & 0.00916 & 0.0126 & 0.0038 \\
\hline Carbon monoxide & $\mathrm{CO}$ & 0.005 & 28.01 & 1.185319 & 0.00593 & 0.0082 & 0.00013 \\
\hline Hydrogen & $\mathrm{H}_{2}$ & 0.000 & 2.0159 & 0.085308 & 0 & 0 & 0 \\
\hline Hydrogen sulphide & $\mathrm{H}_{2} \mathrm{~S}$ & 0.005 & 34.082 & 1.442272 & 0.00721 & 0.0099 & 0 \\
\hline Oxygen & $\mathrm{O}_{2}$ & 0.050 & 31.999 & 1.354124 & 0.06771 & 0.0933 & 0 \\
\hline Water & $\mathrm{H}_{2} \mathrm{O}$ & 0.040 & 18.015 & 0.762354 & 0.03049 & 0.0420 & 0 \\
\hline Nitrogen & $\mathrm{N}_{2}$ & 3.337 & 28.0135 & 1.185467 & 3.95590 & 5.4530 & 0 \\
\hline Argon & $\mathrm{Ar}$ & 0.005 & 39.948 & 1.690508 & 0.00845 & 0.0117 & 0 \\
\hline Carbon dioxide & $\mathrm{CO}_{2}$ & 2.200 & 44.01 & 1.862402 & 4.09729 & 5.6478 & 0.0565 \\
\hline Totals & & 100.000 & & & 72.5457 & 100.0000 & 2.4920 \\
\hline
\end{tabular}

Table 5 Emission factors of methane and nitrous dioxide

\begin{tabular}{|c|c|c|}
\hline Technology used & $\begin{array}{l}\mathrm{CH}_{4} \text { emission } \\
\text { factor } \\
\mathrm{t} \mathrm{CH}_{4} / \mathrm{PJ} \text { gas }\end{array}$ & $\begin{array}{l}\mathrm{N}_{2} \mathrm{O} \text { emis- } \\
\text { sion factor } \\
\mathrm{t} \mathrm{N}_{2} \mathrm{O} / \mathrm{PJ} \\
\text { gas }\end{array}$ \\
\hline Boiler & 0.1 & 0.1 \\
\hline Gas turbine & 8.0 & 0.1 \\
\hline Reciprocating engine (ICE) & 240 & 0.1 \\
\hline
\end{tabular}

\section{Oil-fired power plant}

Similar to gas-fired power plant, emission factor of carbon dioxide $\left(\mathrm{CO}_{2}\right)$ for oil-fired power generation plant may also be calculated from fuel composition of the plant. The calculation is based on the amount of carbon $C_{\mathrm{a}}$ in the fuel using the equation below:

$F_{\mathrm{CO}_{2}}=\frac{C_{\mathrm{a}}}{100} \times \frac{44}{12}, \mathrm{kgCO}_{2} / \mathrm{kgfuel}$

As for gas-fired power plant, emission factors of methane $\left(\mathrm{CH}_{4}\right)$ and nitrous oxide $\left(\mathrm{N}_{2} \mathrm{O}\right)$ for oil-fired power plant cannot be calculated as these gases are only emitted as a result of incomplete combustion. Hence, a program of regular sampling and analysis, or estimation method needs to be adopted. Table 6 gives common emission factors of methane and nitrous oxide, for different technologies employed in gas-fired power plant.
Table 6 Emission factor of methane and nitrous dioxide for oil

\begin{tabular}{llll}
\hline Fuel oil type & Equipment type & $\mathrm{CH}_{4}(\mathrm{t} / \mathrm{PJ})$ & $\mathrm{N}_{2} \mathrm{O}(\mathrm{t} / \mathrm{PJ})$ \\
\hline Residual oil & Boiler & 0.8 & 0.6 \\
Distillate oil & Boiler & 0.04 & 0.6 \\
& Turbine & 4.0 & 0.6 \\
Fuel oil & Boiler & 0.8 & 0.6 \\
& Internal combustion & 4.0 & 0.6 \\
Diesel & Internal combustion & 4.0 & 0.6 \\
\hline
\end{tabular}

\section{Coal-fired power plant}

Emission factor of carbon dioxide $\left(\mathrm{CO}_{2}\right)$ for coal-fired power plant may also be calculated from the amount of carbon in fuel as received or as fired and ash sample of the plant. The equation for emission factor of carbon dioxide is given by:

$F_{\mathrm{CO}_{2}}=\left(\frac{C_{\mathrm{ar}}}{10^{2}}-\frac{C_{\mathrm{a}} \times A_{\mathrm{ar}}}{\left(100-C_{\mathrm{a}}\right) \times 10^{2}}\right) \times \frac{44}{12}$

Emission of methane $\left(\mathrm{CH}_{4}\right)$ is insignificant from combustion in a coal-fired power plant. Similarly, concentration of the emission of nitrous oxide in a coal-fired power plant is normally very low. Table 7 and Table 8 give common emission factors of methane and nitrous oxide, respectively, for different technologies employed in coalfired power plant. 
Table 7 Methane emission factor for coal-fired plant

\begin{tabular}{ll}
\hline Coal technology & $\mathrm{t} \mathrm{CH}_{4} / \mathrm{PJ}$ \\
\hline Integrated gasification combined cycle (IGCC) & 1.0 \\
Pressurised fluidised bed combustor (PFBC) & 1.0 \\
Atmospheric fluidised bed combustor (AFBC) & 1.0 \\
Pulverised coal-fired, dry bottom, wall and tangentially & 0.7 \\
$\quad$ fired & \\
Pulverised coal-fired, wet bottom, cyclone furnace & 0.9 \\
Spreader stokers with and without re-injection & 1.0 \\
Overfeed spreader stokers & 1.0 \\
Underfeed stokers & 14 \\
\hline
\end{tabular}

Table 8 Emission factor of nitrous oxide of coal-fired plant

\begin{tabular}{lll}
\hline Coal technology & $\begin{array}{l}\text { Higher rank coal } \\
\mathrm{t} \mathrm{N}_{2} \mathrm{O} / \mathrm{PJ} \text { coal }\end{array}$ & $\begin{array}{l}\text { Lower } \\
\text { rank } \\
\text { coal } \\
\mathrm{t} \mathrm{N} \mathrm{N}_{2} \mathrm{O} / \\
\mathrm{PJ} \mathrm{coal}\end{array}$ \\
\hline IGCC & 1.0 & 1.4 \\
PFBC & 1.0 & 1.4 \\
AFBC & 40 & 20 \\
Super-critical PF boilers & 0.8 & 1.4 \\
Sub-critical PF boilers & 0.8 & 1.4 \\
Grate-type boilers & 0.8 & 1.4 \\
\hline
\end{tabular}

\section{Actual greenhouse intensity (GI) of power plant}

Actual greenhouse intensity (GI) value is the average emission value for a given pollutant from a source relative to the intensity of its power generation. Commonly, total emission of carbon dioxide equivalence is used in the calculation of GI value.

It is assumed that power generation plant emits three gases of interest: carbon dioxide, methane and nitrous oxide with emission factors; $F_{\mathrm{CO}_{2}}, F_{\mathrm{CH}_{4}}$ and $F_{\mathrm{N}_{2} \mathrm{O}}$, respectively, representing emissions of the respective gases per $\mathrm{kg}$ of fuel consumed by the power plant. Emission factors of methane and nitrous oxide need to be first converted into its carbon dioxide equivalent in order to calculate GI value of the plant. These conversions need to take into account the effects of the different gases on the environment in comparison with carbon dioxide emission.

Furthermore, some power plants may utilise multiple sources of fossil fuels for their power generation. These power plants may either utilise different combinations of fuels simultaneously or utilise one type of fuel at a particular time and another types of fuel at other times, i.e. fuel switching. Fuel switching is beneficial to address the issue of scarcity of fuel supplies as well as reduce greenhouse intensity of the power plant.
If a given power plant is assumed to utilise $N$ different sources of fuel, collective emission factor $F_{\mathrm{CO}_{2} \text { equiv,i }}$ of the plant from the use of fuel $i=1 \ldots N$ may be defined in terms of its carbon dioxide equivalence and is represented by:

$F_{\mathrm{CO}_{2} \text { equiv }, i}=F_{\mathrm{CO}_{2}, i}+21 F_{\mathrm{CH}_{4}, i}+310 F_{\mathrm{N}_{2} \mathrm{O}, i}$

Performance of the power plant must be expressed in terms of total $\mathrm{CO}_{2}$ equivalent released and total annual power sent out by the plant, to obtain GI value of the power plant. It is noted that actual greenhouse intensity for power plant employing multiple sources of fuels $i=1 \ldots N$ must consider total $\mathrm{CO}_{2}$ equivalent released and total annual power sent out from all $N$ sources of fuel. Actual greenhouse intensity (GI) value of the power plant may then be calculated using values taken over time period $T$ using:

$$
\begin{aligned}
\mathrm{GI} & =\frac{\mathrm{EM}_{\mathrm{CO}_{2} \text {,equiv. }}}{E_{\mathrm{so}}} \\
\mathrm{GI} & =\frac{\sum_{i=1}^{N} m_{i} \times F_{\mathrm{CO}_{2} \text { equiv, } \mathrm{i}}}{E_{\mathrm{so}}}
\end{aligned}
$$

Actual greenhouse intensity (GI) has units $\left(\frac{\mathrm{kgCO}_{2} \text { equiv }}{\mathrm{MWh} \text { sentout }}\right)$.

It is noted that sent-out energy $E_{\mathrm{so}}$ is the energy generated at the generator terminals $E_{\mathrm{G}}$ less the energy consumed by the auxiliary load $E_{\mathrm{A}}$ of the plant, and it may be expressed as follows:

$E_{\mathrm{SO}}=E_{\mathrm{G}}-E_{\mathrm{A}}$

As can be seen from Eqs. (5) and (6), GI value of the power plant is related to the amount of greenhouse gases that the plant are emitting $F_{\mathrm{CO}_{2} \text { equiv, } i}$, which in turns is related to emission factors of the different gases, as well as the amount of energy that the power plant is sending out $E_{\mathrm{so}}$. As such, given known emission factors of the different gases from all its fuels' sources, known consumptions of fuels and known amount of energy send out by the plant, actual GI value of the plant can be determined. It can be shown that GI value is closely related to thermal efficiencies of that plant.

Thermal efficiency of the power plant may be defined as the ratio of useful electricity energy output from the plant, over a time period $T$, to the energy source supplied to the unit. In this regard, generated thermal efficiency $\left(\eta_{\mathrm{GEN}}\right)$ ratio of energy generated by the plant to energy value from the fuel that is being fed into the power plant, and Sent-out Thermal efficiency $\left(\eta_{\mathrm{so}}\right)$; ratio of sent-out energy by the plant to energy from the fuel that is being fed into the power plant is given as follows:

$\eta_{\mathrm{GEN}}=\frac{E_{\mathrm{G}}}{\sum_{i=1}^{N} m_{i} \times Q_{i}} \times 60 \times 60 \times 100 \%$ 
$\eta_{\mathrm{so}}=\frac{E_{\mathrm{so}}}{\sum_{i=1}^{N} m_{i} \times Q_{i}} \times 60 \times 60 \times 100 \%$

These two values $\eta_{\mathrm{GEN}}$ and $\eta_{\mathrm{so}}$ are important measures of efficiency of the power plant and are unitless. Alternative expressions for thermal efficiency of power plant are generated heat rate (GHR) and sent-out heat rate (SHR), which are related to $\eta_{\mathrm{GEN}}$ and $\eta_{\mathrm{so}}$, respectively:

$\mathrm{GHR}=\frac{3600}{\eta_{\mathrm{GEN}}} \times 100$

$\mathrm{SHR}=\frac{3600}{\eta_{\mathrm{so}}} \times 100$

Substituting Eq. (9) into the equation for GI value in Eq. (6) gives:

$\mathrm{GI}=\frac{\sum_{i=1}^{N} m_{i} \times F_{\mathrm{CO}_{2} \text { equiv, } \mathrm{i}}}{\eta_{\mathrm{so}} \times \sum_{i=1}^{N} m_{i} \times Q_{i}} \times 60 \times 60 \times 100$

which can also be expressed as:

$\mathrm{GI}=\frac{\sum_{i=1}^{N} m_{i} \times F_{\mathrm{CO}_{2} \text { equiv,i }}}{\sum_{i=1}^{N} m_{i} \times Q_{i}} \times \mathrm{SHR}$

Normally, GI value is calculated for a given output factor or load $(L)$ of the power plant. Output factor or load $(L)$, defined as ratio of energy generated by the power plant over time period $T$ to total energy that the power plant is designed to generate over the same time period, can be represented as:

$L=\frac{E_{\mathrm{G}}}{P_{I} \times T}$

Equations (6), (12) and (13) may be used to find the actual GI value of a given power plant with output factor/ load determined using Eq. (14).

\section{Range of allowable greenhouse intensity value}

For a given power plant, average greenhouse emission of the power plant, expressed as actual GI value of the power plant, may be used to evaluate whether the power plant complies with the power plant energy efficiency standard. This is done by comparing actual GI value with the range of acceptable GI values for the specific power plant; if GI value falls within the allowable range of GI values, the power plant can be said to be in compliance with the power plant energy efficiency standard and vice versa.
The allowable range of GI values is derived from the greenhouse intensity reference $\left(G_{R}\right)$ value, which is specific to the power plant only and varies with its age.

\section{Greenhouse intensity reference $\left(G I_{R}\right)$ value}

Greenhouse intensity reference $\left(\mathrm{GI}_{R}\right)$ value may be calculated from the measured sent-out thermal efficiency of the power plant during the year in which the power plant participated in the power plant efficiency standard. Sent-out thermal efficiency of the power plant needs to be measured for different output factors, henceforth, called the reference sent-out thermal efficiency of the power plant which is a function of output factors i.e. $\eta_{\text {so,ref }}(L)$. These values are then used to determine greenhouse intensity reference $\mathrm{GI}_{R}$ value of the power plant and, consequently, the allowable range of GI values for subsequent years, for different output factors $L$.

For the general cases where the power plant utilises $N$ types of fuels with measured reference sent-out thermal efficiency $\eta_{\text {so,ref }}(L)$ at different output factors $L$, the corresponding greenhouse intensity reference value $\mathrm{GI}_{\mathrm{R}}(L)$ must be calculated in such a way that it reflects the proportion of different types of fuels that are used by the power plant. Greenhouse intensity reference value $\mathrm{GI}_{\mathrm{R}}(L)$ for a power plant utilising $N$ types of fuels for a given output factor/load $L$ may be calculated as:

$\mathrm{GI}_{\mathrm{R}}(L)=\frac{\sum_{i=1}^{N} m_{i} \times F_{\mathrm{CO}_{2} \text { equiv, } \mathrm{i}}}{\eta_{\text {so,ref }}(L) \times \sum_{i=1}^{N} \times m_{i} \times Q_{i}} \times 60 \times 60 \times 100$

It is noted that greenhouse intensity reference value, $\mathrm{GI}_{\mathrm{R}}(L)$, is unique for the power plant under investigation.

\section{Reference lower and upper greenhouse intensity values}

For a given power plant, greenhouse intensity reference, $\mathrm{GI}_{\mathrm{R}}(L)$, may be used to derive the reference lower, $\mathrm{GI}_{\text {Lower }}(L, Y)$, and upper, $\mathrm{GI}_{\mathrm{Upper}}(L, Y)$, values of greenhouse intensity for different values of output factor, $L$. Variable $Y$ denotes the age of the plant since its participation in the standard.

Assuming a non-recoverable degradation performance of not more than $0.2-0.3 \%$ per annum, dictated by the bestperformance criterion of the standard, $\mathrm{GI}_{\text {Lower }}(L, Y)$ and $\mathrm{GI}_{\text {Upper }}(L, Y)$ for different values of output factor, $L$ can be derived. Furthermore, as greenhouse intensity value and references lower and upper values of greenhouse intensity are based on fuel sampling and quantity metering which are prone to errors, allowances are given to reference lower and upper values of greenhouse intensity. Thus, reference lower $\mathrm{GI}_{\text {Lower }}(L, Y)$ and upper $\mathrm{GI}_{\mathrm{Upper}}(L, Y)$ values of greenhouse 
intensity for different values of output factor, $L$ and age of plant, $Y$ may be calculated as follows:

$\mathrm{GI}_{\text {Lower }}(L, Y)=\frac{\mathrm{GI}_{\mathrm{R}}(L)}{1-(Y \times 0.002)}-\left[\frac{\mathrm{GI}_{\mathrm{R}}(L)}{1-(Y \times 0.002)} \times e_{\text {allo. }}\right]$

$\mathrm{GI}_{\mathrm{Upper}}(L, Y)=\frac{\mathrm{GI}_{\mathrm{R}}(L)}{1-(Y \times 0.003)}+\left[\frac{\mathrm{GI}_{\mathrm{R}}(L)}{1-(Y \times 0.002)} \times e_{\text {allo. }}\right]$

The range of greenhouse intensity values between lower and upper values in Eqs. (16) and (17) provides acceptance test for compliance for a given power plant with the power plant efficiency standard. It is noted that the reference lower $\mathrm{GI}_{\text {Lower }}(L, Y)$ and upper $\mathrm{GI}_{\text {Upper }}(L, Y)$ values of greenhouse intensity vary with load factor $L$ and age $Y$ of the power plant.

If actual greenhouse intensity (GI) value of the power plant falls within the range, the power plant is considered to be in compliance with the power plant efficiency standard and vice versa.

\section{Results and discussion}

For simple cases of power plant utilising only a single source of fuel, either coal, natural gas or diesel oil, greenhouse intensity reference value $\mathrm{GI}_{\mathrm{R}}(L)$ may be plotted for different output factors using sent-out thermal efficiency $\eta_{\mathrm{SO}}(L)$ values as basis for calculation. According to the power plant efficiency standard, greenhouse intensity reference value $\mathrm{GI}_{\mathrm{R}}(L)$ may be calculated from reference sent-out thermal

Table 9 Reference efficiencies for the different type of power plant; coal, natural gas and diesel oil power plants, for different output factors or Load

\begin{tabular}{|c|c|c|c|c|}
\hline \multicolumn{5}{|l|}{ Coal } \\
\hline Load & $40 \%$ & $60 \%$ & $80 \%$ & $100 \%$ \\
\hline Boiler efficiency $(\%)$ & 84.80 & 85.00 & 85.30 & 85.40 \\
\hline Turbine efficiency (\%) & 29.00 & 31.00 & 36.00 & 42.00 \\
\hline $\begin{array}{l}\text { Sent-out thermal efficiency } \\
(\%)\end{array}$ & 23.3624 & 25.0325 & 29.1726 & 34.0746 \\
\hline \multicolumn{5}{|l|}{ Natural gas } \\
\hline Boiler efficiency (\%) & 80.85 & 81.15 & 81.30 & 81.50 \\
\hline Turbine efficiency $(\%)$ & 29.00 & 31.00 & 36.00 & 42.00 \\
\hline $\begin{array}{l}\text { Sent-out thermal efficiency } \\
(\%)\end{array}$ & 22.27418 & 23.8987 & 27.8046 & 32.5185 \\
\hline \multicolumn{5}{|l|}{ Diesel oil } \\
\hline Boiler efficiency (\%) & 82.40 & 82.65 & 82.80 & 83.50 \\
\hline Turbine efficiency (\%) & 29.00 & 31.00 & 36.00 & 42.00 \\
\hline $\begin{array}{l}\text { Sent-out thermal efficiency } \\
(\%)\end{array}$ & 22.7012 & 24.3404 & 28.3176 & 33.3165 \\
\hline
\end{tabular}

efficiency $\eta_{\text {SO,ref }}(L)$ values and it is calculated in the year that the power plant decides to participate in the standard. Reference sent-out thermal efficiencies for different types of power plant, coal, natural gas and diesel oil power plants, for different output factors are taken from reference (Manjinder Bajwa 2011) and are given in Table 9.

Gross calorific value of the different sources of fuel is presented in Table 10, while emission factors for natural gas, diesel fuel and coal are presented in Table 11. It is common to regress the plots using third-order polynomial in our case, due to the limited number of $\eta_{\mathrm{SO}}(L)$ for discrete output factors used as the basis for the calculation.

Plots of greenhouse intensity reference value $\mathrm{GI}_{\mathrm{R}}(L)$ for different values of output factors $L$ are given in Fig. 1 for coal, natural gas and diesel oil power plants. Greenhouse intensity reference value provides the basis for calculation of allowable range of GI values of the power plant in subsequent years, in order for the plant to be in compliance with the power plant efficiency standard. It can also give insights into the relationship between the different types of fuels, power plants out load factors and greenhouse intensity values.

Figure 1 clearly shows that $\mathrm{GI}_{R}$ values decrease with an increase in output factor, for all three fuel types considered, indicating that as output factor increases, the power plant is expected to produce less $\mathrm{CO}_{2}$ for a given quantity of energy generated.

This is because turbine or boiler running at part load tends to have lower efficiency than running at full load, resulting in the plant to have lower thermal efficiency (Nag 2008). This can also be clearly seen from Table 9. Turbine running at full load operates at higher firing temperature compared to turbine running at part load, with the higher temperature providing a better condition for complete combustion. On the other hand, lower firing temperature resulting from turbines running at part load causes quenching of oxidation reaction, especially near the relatively cold areas like the wall of the combustion chamber or furnace. Incomplete combustion produces unwanted carbon monoxide and, consequently, reduces efficiency of the turbine.

Furthermore, Fig. 1 also demonstrates that over all range of output factors, greenhouse intensity reference value $\mathrm{GI}_{\mathrm{R}}(L)$ for natural gas power plant is expected to perform more efficiently in terms of $\mathrm{CO}_{2}$ produced per energy generated, followed by diesel oil power plant and lastly, by the coal power plant. This is indeed expected due to the characteristics of the natural gas, in terms of its gross calorific value and emission factors.

Table 10 Gross calorific value of fuel

\begin{tabular}{ll}
\hline Natural gas (Malaysia 2006) & $51.286 \mathrm{MJ} / \mathrm{kg}$ \\
Diesel oil (Staffell 2011) & $45.6 \mathrm{MJ} / \mathrm{kg}$ \\
Coal (Agency 1998) & $32.564 \mathrm{MJ} / \mathrm{kg}$ \\
\hline
\end{tabular}


Table 11 Emission factor for gas, fuel and coal

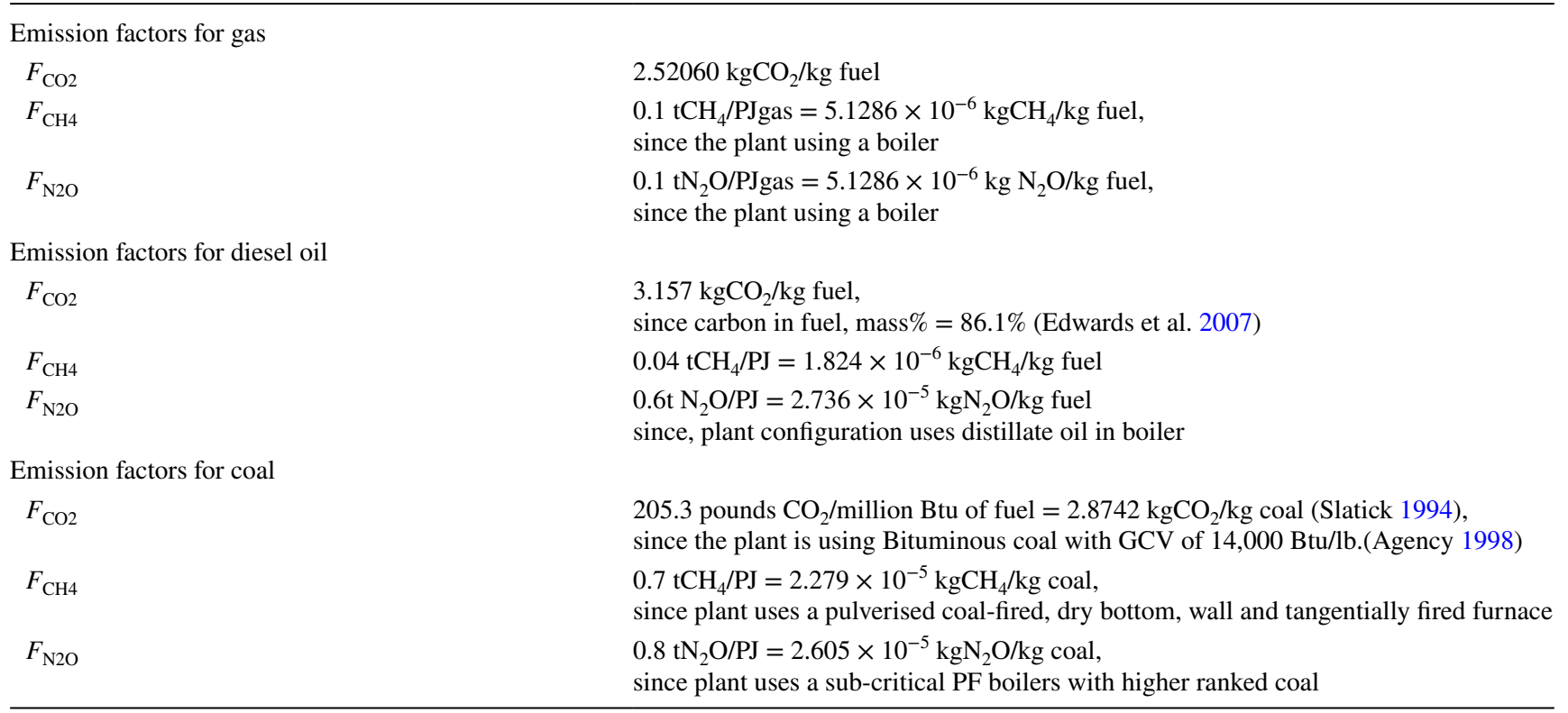

Fig. 1 Reference greenhouse intensity value $\mathrm{GI}_{\mathrm{R}}$ for different output factors, for coal, natural gas and diesel power plants

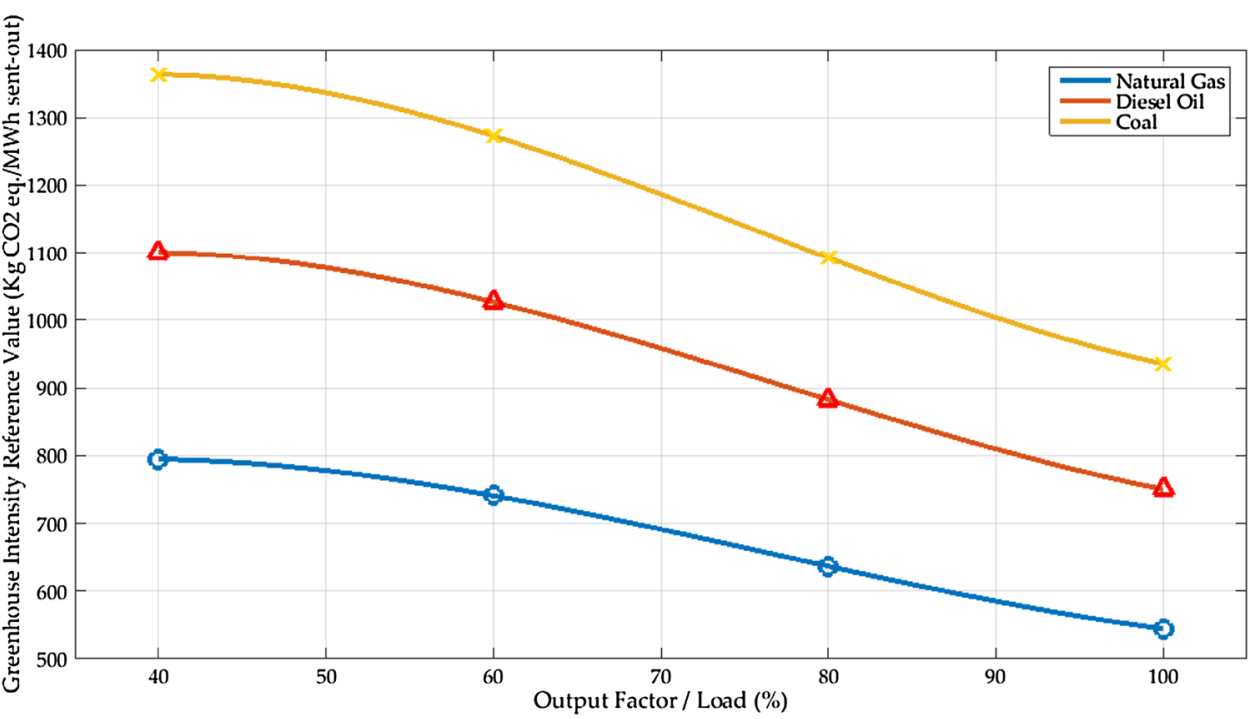

Furthermore, with carbon dioxide' emission factor of $2.52060 \mathrm{kgCO}_{2} / \mathrm{kg}$ fuel (Malaysia 2006), natural gas has the lowest emission factors as compared to diesel oil and coal. Diesel oil, the most popular fuel oil used in power generation industry, is classified as a distillate fuel oil, having a carbon mass percentage of $86.1 \%$ (Edwards et al. 2007) and carbon dioxide's emission factor value of $3.157 \mathrm{kgCO}_{2} / \mathrm{kg}$ fuel. The most common type of coal used in the country is bituminous coal with GCV of $14,000 \mathrm{Btu} / \mathrm{lb}$ (Agency 1998), with carbon dioxide's emission factor value of $2.8742 \mathrm{kgCO}_{2} /$ $\mathrm{kg}$ coal (Slatick 1994). Bituminous coals are classified as the best coals for power generation due to its higher carbon content, resulting in higher energy content (Kentucky 2012) compared to other types of coal. 
Apart from fuel type, equipment technology is another factor that influences emission factors and efficiency of a power plant. For example, burning gas in a reciprocating engine will yield methane's emission factor of $240 \mathrm{t} \mathrm{CH}_{4} /$ PJgas, while burning in a boiler and gas turbine only yield 0.1 and $8.0 \mathrm{t} \mathrm{CH}_{4} / \mathrm{PJgas}$, respectively. Carbon capture and storage (CCS) technology (Institute 2007) may also be adopted for the purpose of controlling greenhouse gases. To improve efficiency of the power plant, integrated gasification combined cycle (IGCC) technology and ultra-supercritical power plant may also be considered. Ultra-supercritical power plant is able to reach a thermal efficiency of 50-55\% compared to $39 \%$ efficiency obtained from a regular sub-critical power plant. Details of technologies that can be adopted are, however, beyond the scope of this paper.

Plots of lower and upper values of greenhouse intensity values $\mathrm{GI}_{\text {Lower }}$ and $\mathrm{GI}_{\text {Upper }}$ against output factor $L$ and age of the plant $Y$ are given in Figs. 2, 3 and 4, for natural gas, diesel oil and coal power plants, respectively. Maximum error allowance $e_{\text {allo. }}=1.5 \%$ is assumed.

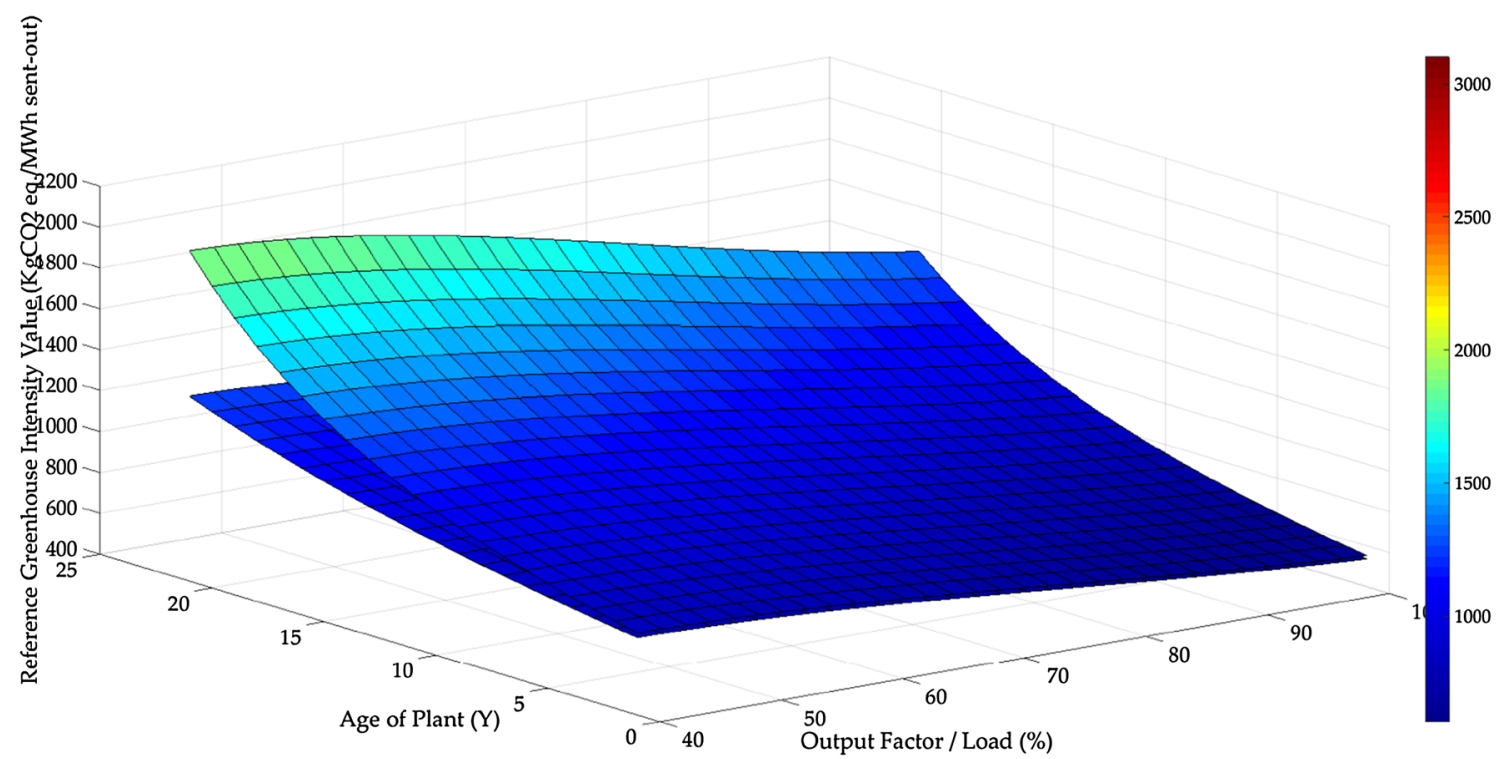

Fig. 2 Lower and upper reference greenhouse intensity values $\left(\mathrm{GI}_{\text {Lower }}\right.$ and $\left.\mathrm{GI}_{\mathrm{Upper}}\right)$ for different output factors and age of power plant, for natural gas power plant

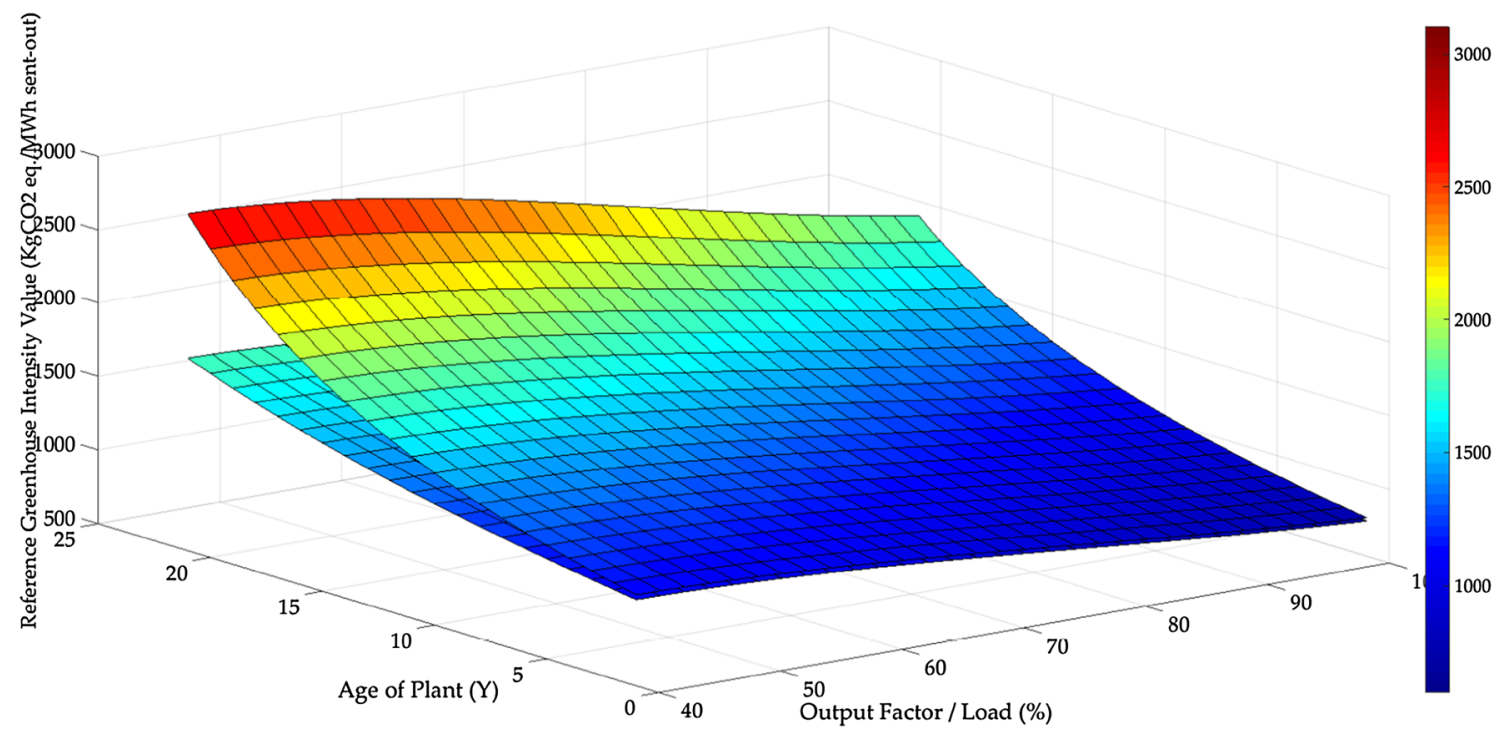

Fig. 3 Lower and upper reference greenhouse intensity values $\left(\mathrm{GI}_{\text {Lower }}\right.$ and $\mathrm{GI}_{\mathrm{Upper}}$ ) for different output factors and age of power plant, for diesel oil power plant 


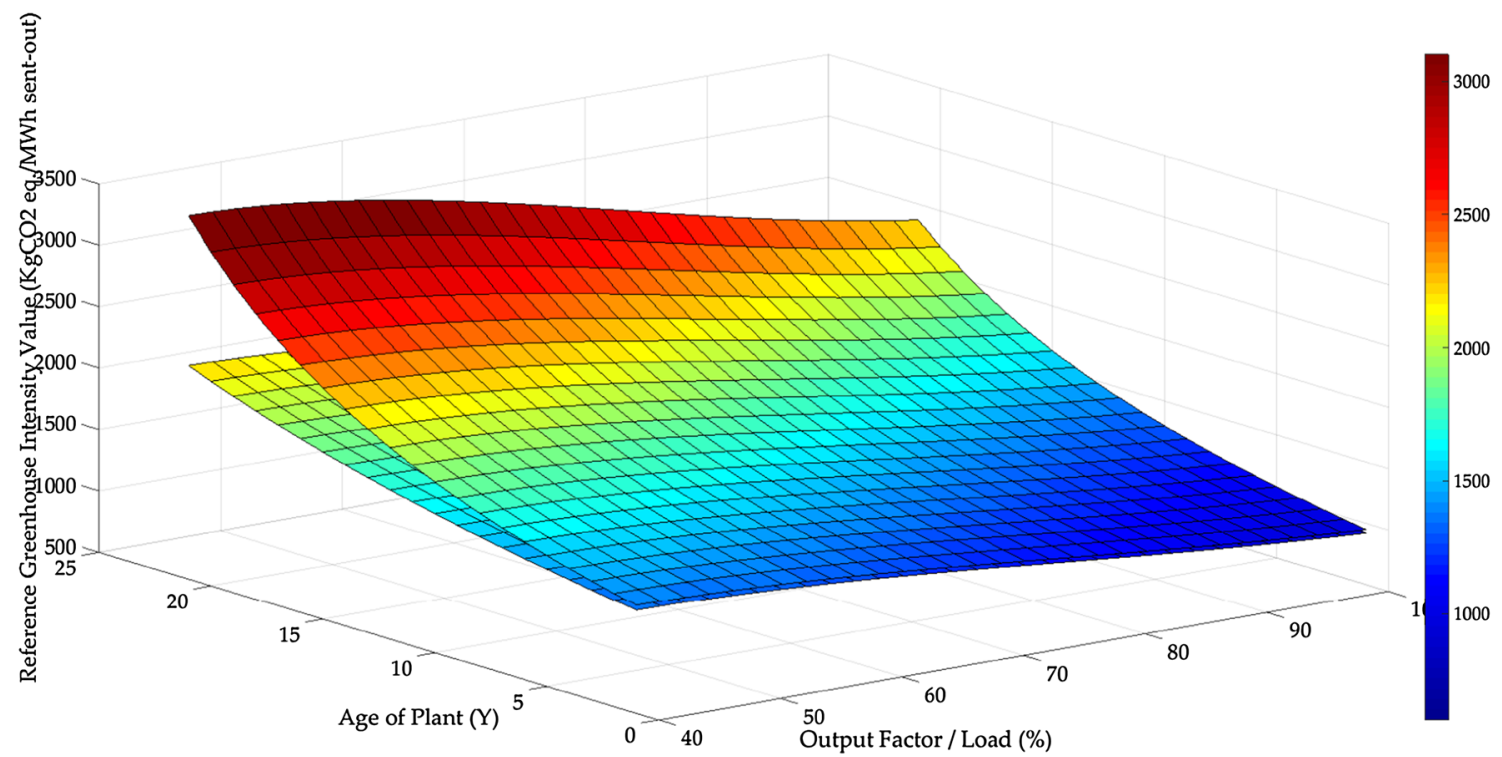

Fig. 4 Lower and upper reference greenhouse intensity values $\left(\mathrm{GI}_{\text {Lower }}\right.$ and $\left.\mathrm{GI}_{\mathrm{Upper}}\right)$ for different output factors and age of power plant, for coal power plant

Table 12 Multi-fuel-fired boiler thermal power plant

\begin{tabular}{ll}
\hline Year & 2014 \\
\hline Age of plant & 10 years \\
Annual average output factor & $100 \%$ \\
Capacity & $1000 \mathrm{MW}$ \\
Capacity factor & $100 \%$ (base-load plant) \\
Types of fuel used & Natural gas, diesel oil, coal \\
Tonnes of fuel used (Office 2001) & \\
(1) Natural gas & 210,200 tpa \\
(2) Diesel oil & 90 pa \\
(3) Coal & 85,050 tpa \\
Electricity generated per year & $950,000 \mathrm{MWh}$ \\
Electricity sent out per year & $902,500 \mathrm{MWh}$ (Auxiliaries =5\%)
\end{tabular}

The reference lower and upper greenhouse intensity values give the best practice range for similar power plant, using non-recoverable degradation of not more than $0.2-0.3 \%$ per annum, with the reference upper greenhouse intensity value providing limit on the compliance with the power plant efficiency standard. Greenhouse intensity value of a plant above the upper reference GI value indicates that the power plant is not in compliance with the power plant efficiency standard.

It is clear from Figs. 2, 3 and 4 that reference lower and upper greenhouse intensity values increase as the power plant ages, consistently across all three fuel types. As natural gas is the most efficient among the three fuel types considered, it is expected that reference upper greenhouse intensity value for natural gas to be lower as compared to other fuel types. This is evident by comparing the above three figures.

Power plant utilising all three (3) sources of fossil fuels may now be considered with performance data given in Table 12. Two scenarios are considered in this paper:

1. The power plant has already participated in the power plant efficiency standard during its start of operation. As such, calculations need to be performed in order to investigate whether the power plant is in compliance with the previously agreed standards, in the current year

2. The power plant has recently agreed to participate in the power plant efficiency standard and needs to find its greenhouse intensity reference value $\mathrm{GI}_{\mathrm{R}}(L)$ based on its current sent-out thermal efficiency given in Table 12, i.e. the sent-out thermal efficiency in Table 12 is taken as the measured reference sent-out thermal efficiency. This shall form the basis for calculating reference lower and upper greenhouse intensity values of the power plant, to ensure its future compliance with the power plant efficiency standard.

For the first scenario, greenhouse intensity reference value $\mathrm{GI}_{\mathrm{R}}$ for different output factors of the power plant under consideration is depicted in Fig. 5. Reference sentout thermal efficiency $\eta_{\mathrm{SO}}(L)$ of the plant at the start of its operation is taken to be the mass weighted-average sent-out thermal efficiency as given in Table 9. Details of the calculations to determine the greenhouse intensity reference value $\mathrm{GI}_{\mathrm{R}}$ for the four output factor are given in Table 13, values of which are then regressed using third-order polynomial to 
Fig. 5 Greenhouse intensity reference values $\left(\mathrm{GI}_{\mathrm{R}}\right)$ for different output factors for the power plant under consideration (employing three (3) fuels) as well as natural gas, diesel oil and coal power plants

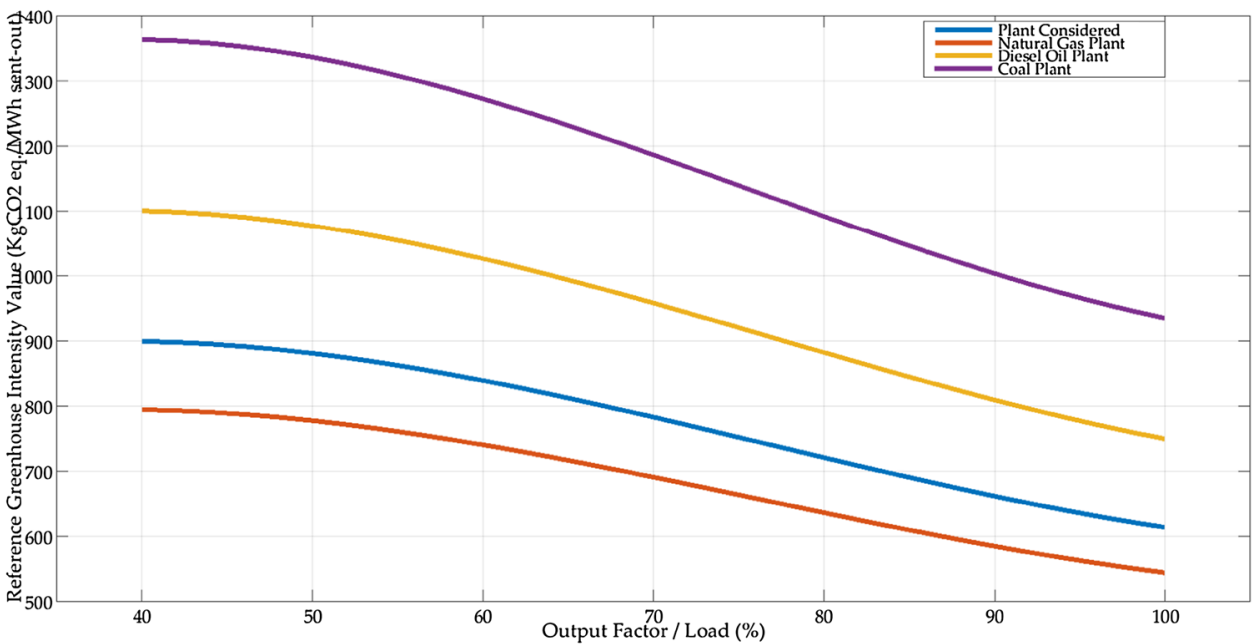

Table 13 Actual and reference greenhouse intensity calculation

\begin{tabular}{|c|c|c|c|c|}
\hline Description & Natural gas & Diesel oil & Coal & Total/weighted average \\
\hline Fuel, tpa & 210,200 & 90 & 85,050 & 295,340 \\
\hline$Q_{\mathrm{gr}, \mathrm{as}}, \mathrm{MJ} / \mathrm{kg}$ & 51.286 & 45.6 & 32.564 & 43.15 \\
\hline$F_{\mathrm{CO} 2}$ & 2.52060 & 3.157 & 2.8742 & 2.622 \\
\hline$F_{\mathrm{CH} 4}$ & $5.1286 \mathrm{E}-06$ & $1.824 \mathrm{E}-06$ & $2.736 \mathrm{E}-05$ & $1.025 \mathrm{E}-05$ \\
\hline$F_{\mathrm{N} 2 \mathrm{O}}$ & $5.1286 \mathrm{E}-06$ & $2.279 \mathrm{E}-05$ & $2.605 \mathrm{E}-05$ & $1.112 \mathrm{E}-05$ \\
\hline Total $\mathrm{CO}_{2}$ equiv $(t)$ & 530190 & 284.90 & 245180 & 775,650 \\
\hline$F_{\mathrm{CO} 2}$ (equiv) & 2.5223 & 3.1655 & 2.8828 & \\
\hline MWh sent out & & & & 902,500 \\
\hline $\mathrm{kgCO}_{2} / \mathrm{MWh}$ sent out & & & & 859.442 \\
\hline \multicolumn{5}{|c|}{ Reference performance @ 100\% output factor } \\
\hline Sent-out thermal efficiency, $\%$ & 33.3165 & 32.5187 & 34.0746 & 33.5346 \\
\hline $\mathrm{GI}_{\mathrm{R}}, \mathrm{kgCO}_{2} / \mathrm{MWh}$ & & & & 614.3395 \\
\hline \multicolumn{5}{|c|}{ Reference performance @ 80\% output factor } \\
\hline Sent-out thermal efficiency, $\%$ & 28.3176 & 27.8046 & 29.1726 & 28.5637 \\
\hline $\mathrm{GI}_{\mathrm{R}}, \mathrm{kgCO}_{2} / \mathrm{MWh}$ & & & & 721.2525 \\
\hline \multicolumn{5}{|c|}{ Reference performance @ 60\% output factor } \\
\hline Sent-out thermal efficiency, $\%$ & 24.3404 & 23.8987 & 25.0325 & 24.5396 \\
\hline $\mathrm{GI}_{\mathrm{R}}, \mathrm{kgCO}_{2} / \mathrm{MWh}$ & & & & 839.5261 \\
\hline \multicolumn{5}{|c|}{ Reference performance @ 40\% output factor } \\
\hline Sent-out thermal efficiency, $\%$ & 22.7012 & 22.2742 & 23.3624 & 22.8915 \\
\hline $\mathrm{GI}_{\mathrm{R}}, \mathrm{kgCO}_{2} / \mathrm{MWh}$ & & & & 899.9686 \\
\hline
\end{tabular}

obtain Fig. 5. Also depicted in Fig. 5 are greenhouse intensity reference values $\mathrm{GI}_{\mathrm{R}}$ of power plants utilising only a single source of fuel, either natural gas, diesel oil or coal.

As can be seen from Fig. 5, the power plant under consideration has relatively lower $\mathrm{GI}_{\mathrm{R}}$ value as compared to power plants utilising diesel or coal only, but higher $\mathrm{GI}_{\mathrm{R}}$ value as compared to power plant utilising natural gas only. These are observed at all output factors. In fact, depending on the proportion of fuels used, $\mathrm{GI}_{\mathrm{R}}$ value may vary between the most efficient (natural gas) to the least efficient (coal). As more natural gases are used, $\mathrm{GI}_{\mathrm{R}}$ value of the plant approaches the $\mathrm{GI}_{\mathrm{R}}$ value of plant utilising natural gas only.

Figure 6 shows the lower and upper reference values of greenhouse intensity $\mathrm{GI}_{\text {Lower }}$ and $\mathrm{GI}_{\text {Upper }}$ against output factor $L$ and age of the plant since its participation in the standards $Y$ for the particular power plant under consideration. Similar to previous figures, maximum error allowance $e_{\text {allo. }}=1.5 \%$ is assumed. The greenhouse intensity reference value $\mathrm{GI}_{\mathrm{R}}$ provides the basis for calculating $\mathrm{GI}_{\text {Lower }}$ and $\mathrm{GI}_{\text {Upper }}$ over the lifetime of the power plant, to ensure compliance with power plant efficiency standard, 


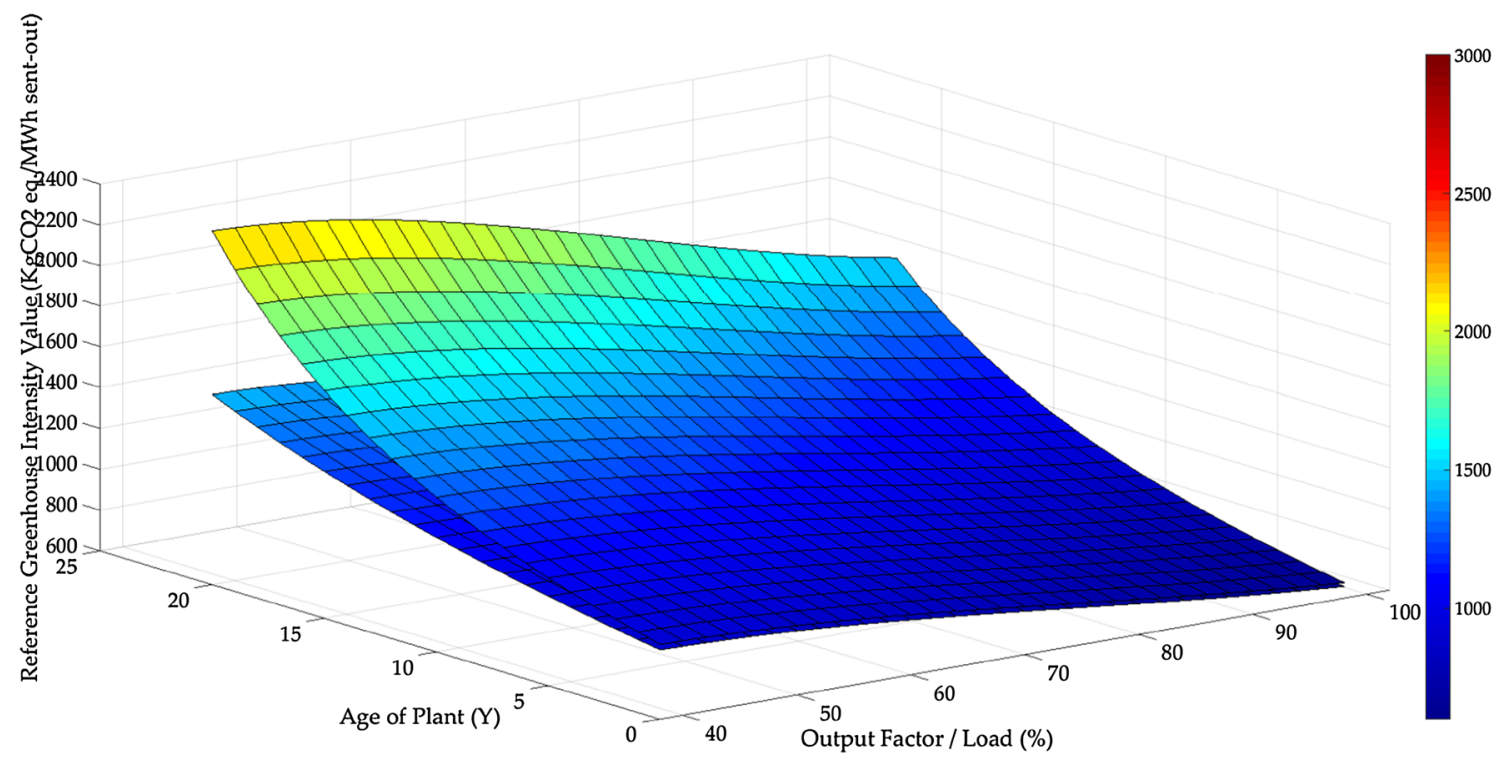

Fig. 6 Lower and upper reference greenhouse intensity values $\left(\mathrm{GI}_{\mathrm{Lower}}\right.$ and $\mathrm{GI}_{\mathrm{Upper}}$ ) for different output factors and age of power plant, for the power plant under consideration, for scenario 1

by ensuring that non-recoverable degradation of the plant does not exceed more than $0.2-0.3 \%$ per annum. For compliance, the greenhouse intensity value of the power plant must remain below upper reference value of greenhouse intensity $\mathrm{GI}_{\mathrm{Upper}}$.

$\mathrm{GI}_{\text {Lower }}$ and $\mathrm{GI}_{\text {Upper }}$ values are increasing with the age of the plant $Y$. Comparison between Figs. 6 with 2, 3 and 4 shows that $\mathrm{GI}_{\text {Lower }}$ and $\mathrm{GI}_{\text {Upper }}$ values for the power plant under consideration lie above the $\mathrm{GI}_{\text {Lower }}$ and $\mathrm{GI}_{\text {Upper }}$ values for plant utilising natural gas only, due to the utilisation of multiple fuels.

Since the power plant is 10 years old, the 3D plot in Fig. 6 may be dissected at year $Y=10$ to give Fig. 7, to show curves for lower $\left(\mathrm{GI}_{\text {Lower }}\right)$ and upper $\left(\mathrm{GI}_{\mathrm{Upper}}\right)$ reference greenhouse intensity values at different output factors. The greenhouse intensity reference values $\left(\mathrm{GI}_{\mathrm{Ref}}\right)$ for different output factors are also plotted on the same figure.

Greenhouse intensity value (GI) of the power plant under consideration at year $Y=10$ with $L=100 \%$ is calculated to be $\mathrm{GI}=859.4461 \mathrm{Kg}$ of $\mathrm{CO}_{2}$ equiv./MWh sent - out and plotted in Fig. 7. Details of the calculation are given in Table 13. It can be clearly seen that GI value of the power plant is between $\mathrm{GI}_{\text {Lower }}$ and $\mathrm{GI}_{\text {Upper }}$ values and hence in compliance with the power plant efficiency standard. In fact, with $Y=10$ and $L=100 \%$, any GI values below approx. $890 \mathrm{Kg}$ of $\mathrm{CO}_{2}$ equiv./MWh sent - out would satisfy the requirements for the power plant efficiency standard.
Fig. 7 Lower, upper reference greenhouse intensity values $\left(\mathrm{GI}_{\text {Lower }}\right.$ and $\left.\mathrm{GI}_{\text {Upper }}\right)$, greenhouse intensity reference value $\left(\mathrm{GI}_{\mathrm{Ref}}\right)$ and greenhouse intensity value for the power plant under consideration, at year 10 for scenario 1

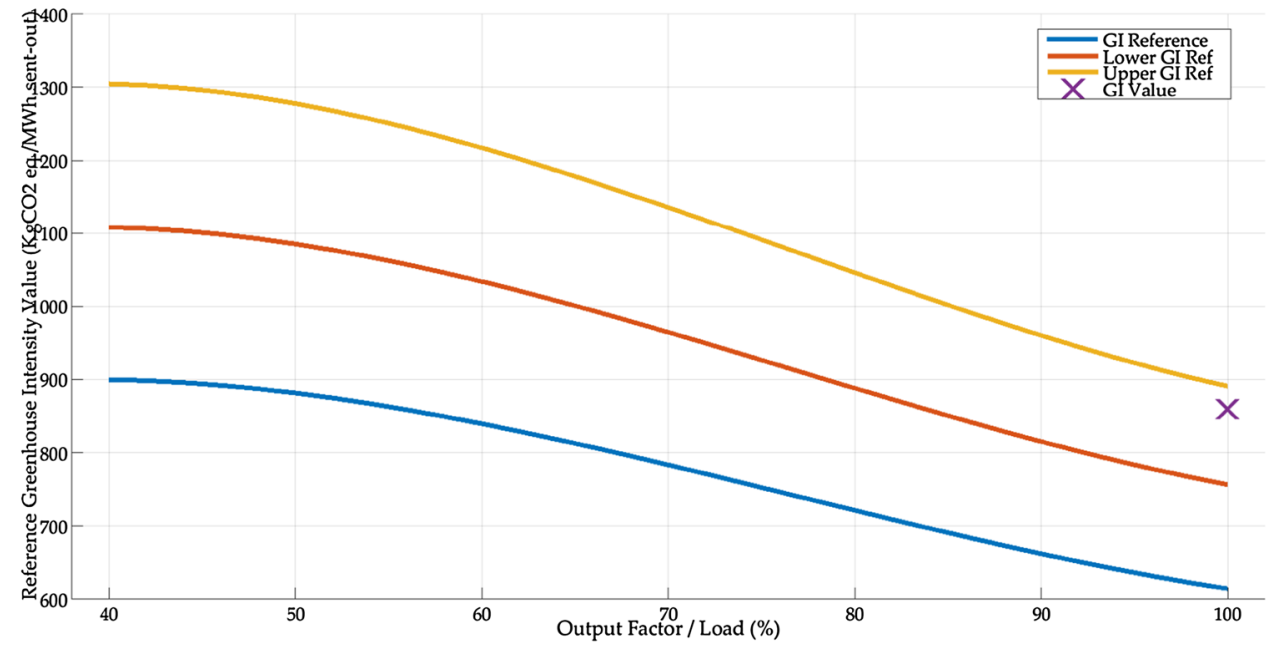


In scenario 2, the power plant under consideration is taken to be an existing power plant which has recently agreed to adhere to the power plant efficiency standard. The plant is an existing power plant with 10 years of age, and hence, procedures for an existing or refurbished plant are to be followed. Performance data in Table 12 may be used to determine the greenhouse intensity reference value $\left(\mathrm{GI}_{\text {Ref }}\right)$ for the specific power plant, which in turn shall be used to determine lower and upper reference values of greenhouse intensity $\mathrm{GI}_{\mathrm{Lower}}$ and $\mathrm{GI}_{\mathrm{Upper}}$. As no data are available for output factor other than $100 \%$, Table 9 may be used to provide us estimates at different output factors.

The bottom curve in Fig. 8 depicts the greenhouse intensity reference value $\left(\mathrm{GI}_{\mathrm{Ref}}\right)$ at different output factors for the power plant. Figure 9 shows lower and upper reference values of greenhouse intensity values $\mathrm{GI}_{\text {Lower }}$ and $\mathrm{GI}_{\mathrm{Upper}}$ against output factor $L$ and age of the plant since participation in the standards, $Y$ for the power plant under consideration. Again, $\mathrm{GI}_{\text {Lower }}$ and $\mathrm{GI}_{\text {Upper }}$ values increase with age of the plant $Y$. It needs to be highlighted that age of the plant as indicated on the $z$-axis in Fig. 9 corresponds to the number of years that the power plant has participated in the standard and not the actual age of the plant.

Given a specific year for testing for compliance, the curve can be used to ensure compliance of the particular power plant to the standard; if calculated GI value for the specific year is less than the $\mathrm{GI}_{\mathrm{Upper}}(L, Y)$ for year $Y$ at particular load

Fig. 8 Lower, upper reference greenhouse intensity values $\left(\mathrm{GI}_{\text {Lower }}\right.$ and $\left.\mathrm{GI}_{\text {Upper }}\right)$, greenhouse intensity reference value $\left(\mathrm{GI}_{\text {Ref }}\right)$ and greenhouse intensity value for the power plant under consideration, at year 10 for scenario 2
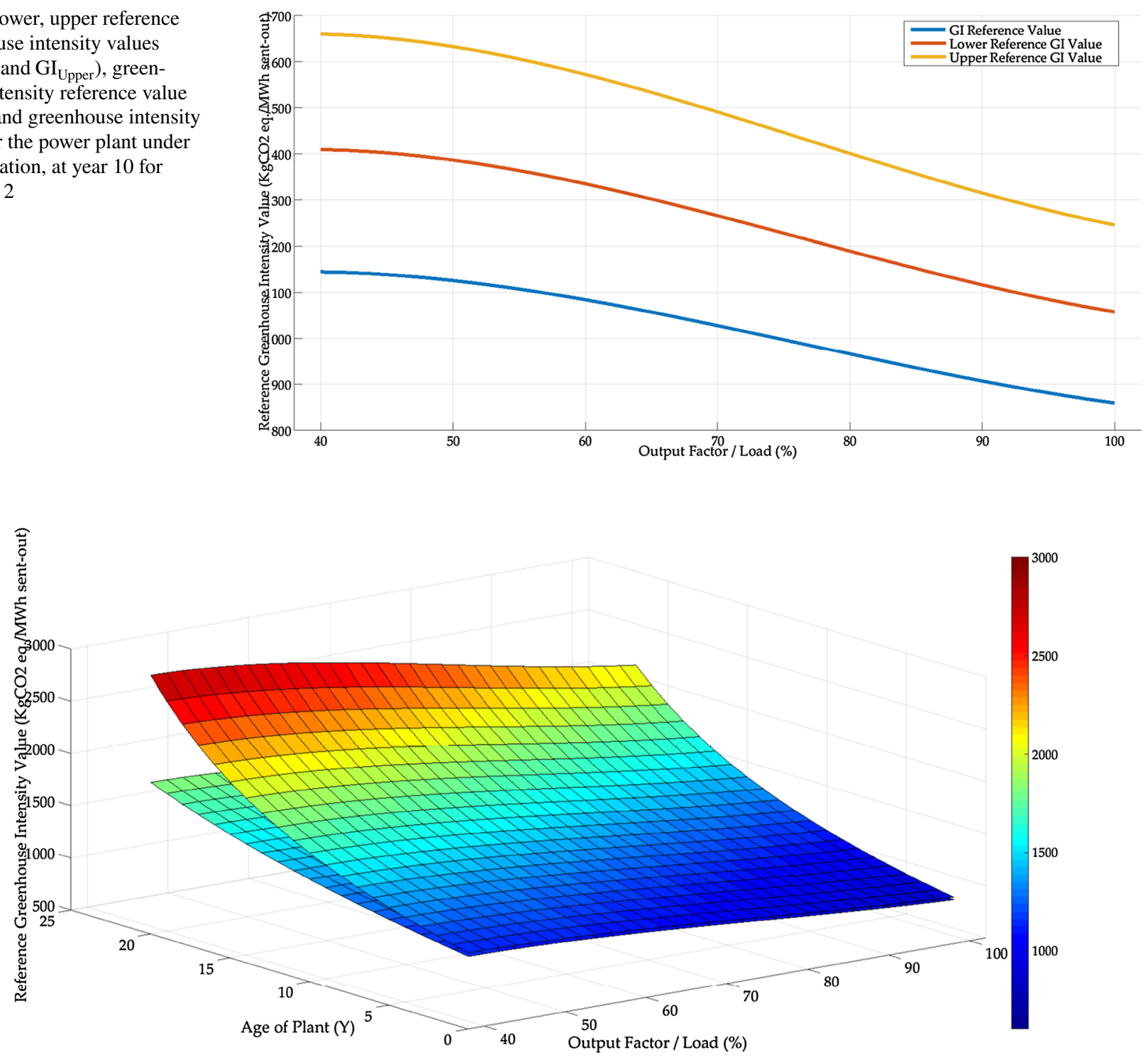

Fig. 9 Lower and upper reference greenhouse intensity values $\left(\mathrm{GI}_{\text {Lower }}\right.$ and $\left.\mathrm{GI}_{\mathrm{Upper}}\right)$ for different output factors and age of power plant, for the power plant under consideration, for scenario 2 
factor, then the power plant can be said to be in compliance with the power plant efficiency standard.

On the 10th year since the plant's participation in the power plant efficiency standard (since the power plant is currently 10 years old, the 10th year corresponds to when the power plant is 20 years old), lower and upper reference GI values, $\mathrm{GI}_{\text {Lower }}$ and $\mathrm{GI}_{\text {Upper }}$, are given in Fig. 8. For output factor of $L=100 \%$ at year $Y=10$, GI value below $1250 \mathrm{Kg}$ of $\mathrm{CO}_{2}$ equiv./MWh sent - out indicates that the power plant is in compliance with the power plant efficiency standard.

It is noted that greenhouse intensity reference $\left(\mathrm{GI}_{R}\right)$ of a power plant is calculated based on the proportion of different sources of fuels it utilised and also the measured reference sent-out thermal efficiency $\left(\eta_{\text {so,ref }}\right)$ during the year of its participation in the power plant efficiency standard. While new plant needs to abide to the world's best practice sent-out thermal efficiency $\eta_{\text {so,WBP }}$ when first participating in the standard, there is no such requirement for existing/ refurbished power plant. Existing/refurbished power plant needs only use its measured sent-out thermal efficiency as its reference. Naturally, some power plants, especially the existing/refurbished power plants, would have higher $\mathrm{GI}_{R}$ values than others and, consequently, may have higher values of greenhouse intensity but yet still comply with the standard.

Furthermore, it is expected that the longer the power plant has participated in the standards, the higher its lower and upper reference greenhouse intensity values $\left(\mathrm{GI}_{\text {Lower }}\right.$ and $\left.\mathrm{GI}_{\text {Upper}}\right)$. Hence, older plants are allowed to have higher GI values than the newer power plants.

\section{Conclusions}

One of the most effective ways for controlling emission from power plant is via the introduction of power plant efficiency standard. With the ultimate goal of improving air quality by reducing greenhouse gas emissions from the power sector, introduction of standard would encourage power generation companies to pay more attention to their emission quality and efficiency, by using energy efficient fuel sources, running their power plant at optimum conditions and considering latest available technologies.

This paper shows methodologies for calculating greenhouse intensity value, its reference value as well as its allowable range, via case study of a specific power plant in Malaysia. In Malaysia, power plant efficiency standard is yet to be introduced, and hence, this paper can be set as a reference, for the Commission and Ministry of Energy, Green Technology and Water (KeTTHA), for evaluating greenhouse intensity for power plants specifically in Malaysia. However, it should be noted that the methodologies presented are applicable for power plants worldwide.
It has been shown that among the different sources of fuels considered, natural gas has the highest gross calorific value and hence is the preferred primary source of fuel in order to minimise the plant's greenhouse intensity. Furthermore, benefit obtained from running power plant at full load has also been shown. By considering the performance data of a 10-year-old base-load multi-fuel-fired power plant, it has been shown that the power plant satisfies the power plant efficiency standard, with GI value of $859.4461 \mathrm{kgCO}_{2} / \mathrm{MWh}$ residing within the allowable range of between 760 and 890 $\mathrm{Kg}$ of $\mathrm{CO}_{2}$ equiv./MWh sent - out.

This evaluation is, however, based on an assumed greenhouse intensity reference value, without real validation and test on any specific power plant. Complete validations are first needed on selected power plants in Malaysia, before it can be introduced to all power generation companies. Laws and regulations must also be considered, with penalty such as carbon tax to power plant deemed to be in noncompliance with the standard. Imposing lower electricity selling prices to power plant that is deemed to have high GI value may also be considered. These strategies are needed to encourage power companies to upgrade their plants regularly, improving their efficiency and curbing unnecessary emissions. Other tasks such as life cycle cost analysis, accounting and taxes, laws and regulations, future technology forecast also need to be performed before introducing the standard.

Finally, it is hoped that this paper shall pave the way for further research work in the area and is able to somehow facilitate the implementation of power plant efficiency standard, not only in Malaysia, but also for other countries worldwide which have not implemented the standard.

Open Access This article is distributed under the terms of the Creative Commons Attribution 4.0 International License (http://creativecommons.org/licenses/by/4.0/), which permits unrestricted use, distribution, and reproduction in any medium, provided you give appropriate credit to the original author(s) and the source, provide a link to the Creative Commons license, and indicate if changes were made.

\section{Appendix A}

This section provides description of power plant efficiency standard that may be adopted. The methodology demonstrated shall roughly follows the generator efficiency standard (GES) (Office 2000b) in Australia, with the country ranked third out of one hundred and seventy-eight countries throughout the world based on Environmental Performance Index 2014 (Hsu 2014). The standards encompass procedure for newly built power plant as well as existing/refurbished power intending to participate in the standards. Flow chart depicting the procedures is given in Fig. 10. 
Fig. 10 Power plant efficiency standard-process flow chart



\section{A1 Procedure for new power plant}

For new power plant, there are five (5) steps that need to be taken in order to abide by the power plant efficiency standard. Basically, principle for the standards for new plant selection is similar to the world's best practice's concept, requiring the new plant to implement the best available technology and life cycle cost (Australian Government 2014):

1. Plan and do economic and technical researches on new plant options, which take into consideration factors such as site selections, alternative fuels, water availability and requirements for emissions, for example, emissions of 
Table 14 WBP thermal efficiency classification

\begin{tabular}{llll}
\hline Fuel & Technology & Unit size MW & WBP- $\eta_{\text {SO }}$ \\
\hline Black coal & Super-critical & $\geq 250$ & 41.7 \\
& Sub-critical & $<250$ & 37.7 \\
& IGCC & & 49.4 \\
& PFBC & & 38.2 \\
Brown coal & Super-critical & $\geq 250$ & 31.4 \\
& Sub-critical & $<250$ & 29.0 \\
& IGCC & & 44.7 \\
\multirow{4}{*}{ Natural gas } & PFBC & & 34.2 \\
& OCGT & $\geq 100$ & 35.5 \\
& & $<100$ & 37.6 \\
Fuel oil & CCGT & $\geq 250$ & 52.0 \\
& & $<250$ & 46.7 \\
& OCGT & $\geq 100$ & 35.5 \\
& & $<100$ & 37.6 \\
& CCGT & $\geq 250$ & 52.0 \\
& & $<250$ & 46.7 \\
\hline
\end{tabular}

oxides of nitrogen, oxides of sulphur, and particulates, and transmission line losses,

2. Determine the world's best practice $\eta_{\mathrm{SO}}$ for the plant according to fuel types. WBP- $\eta_{\text {SO }}$ for different types of power plants are indicated in Table 14.

3. Compare the $\eta_{\mathrm{SO}}$ of the as-planned new plant with the adjusted WBP- $\eta_{\text {so. }}$

4. If it is less than the adjusted $\mathrm{WBP}-\eta_{\mathrm{so}}$, repeat Step 1 to re-evaluate the choice.

5. After plant commissioning and final acceptance/performance testing, calculate the greenhouse intensity reference value $\mathrm{GI}_{\mathrm{R}}(L)$ for different output factors $L$, using test results on the measured reference sent-out thermal efficiency values.

6. $\quad \eta_{\text {so,ref }}(L)$ at different output factors $L$ may be used to calculate the reference lower and upper greenhouse intensity values $\mathrm{GI}_{\text {Lower }}(L, Y)$ and $\mathrm{GI}_{\mathrm{Upper}}(L, Y)$ for different output factors $L$ and age of the power plant since participation in the standards, for compliance testing in subsequent years.

\section{A2 Procedure for existing/refurbished power plant}

For existing/refurbished plant, there are six steps necessary to be taken in order to determine greenhouse efficiency standards. The procedure is as follows (Australian Government 2014):

1. Documentation of initial performance: Document or estimate the best available performance of the plant, for example, the design condition when the plant was subjected to performance testing either as new or as refurbished. Post-commissioning, heat rate test is also accepted,

2. Retake and recalculate $\eta_{\mathrm{GEN}}$ and $\eta_{\mathrm{SO}}$ to reflect operation using current fuels, adjusted for additional heat losses that would occur under normal as-new or as-refurbished operating conditions but were not included in the initial performance/acceptance tests if applicable. This must be performed across different output factors $L$ to give reference sent-out thermal efficiency $\eta_{\text {so,ref }}(L)$,

3. Calculate greenhouse intensity reference value $\left(\mathrm{GI}_{\mathrm{R}}(L)\right)$ as $\mathrm{kgCO}_{2}$ equiv./MWh sent out relative to output factor to produce the "reference" greenhouse intensity curve,

4. Calculate the lower and upper reference values, $\mathrm{GI}_{\text {Lower }}(L)$ and $\mathrm{GI}_{\text {Upper }}(L)$, of greenhouse intensity relative to a range of loads $\left(\mathrm{GI}_{\mathrm{R}}(L)\right)$, for a given year $(Y)$ using polynomials to regress the data. An allowance of \pm 0.015 (Office 2001) is given to each lower and upper values due to measurement error,

5. Calculate the actual greenhouse intensity. Compare the actual greenhouse intensity with the corresponding allowable range at the average output factor for the year illustrated on the greenhouse intensity curve.

\section{References}

Agency USEP (1995) emissions factors \& AP 42, compilation of air pollutant emission factors technology transfer network clearinghouse for inventories \& emissions factors 1

Agency USEP (1998) AP 42 emission factor, bituminous and subbituminous coal combustion technology transfer network clearinghouse for inventories \& emissions factors 1

Agency USEP (2014)

Agency USEP (2015) Carbon pollution standards

Ali R, Daut I, Taib S (2012) A review on existing and future energy sources for electrical power generation in Malaysia. Renew Sustain Energy Rev 16:4047-4055. https://doi.org/10.1016/j. rser.2012.03.003

Archives TSO (2005) The star online, major blackouts in Malaysia

Augustus de Melo C, de Martino Jannuzzi G (2010) Energy efficiency standards for refrigerators in Brazil: a methodology for impact evaluation. Energy Policy 38:6545-6550. https://doi. org/10.1016/j.enpol.2010.07.032

Australian Government (2014) Efficiency standard for power generation. Department of the Environment, Canberra

Bernstein L (2007) Climate change 2007: synthesis report

de Alencar Medeiros Filho J, de Gusmao Lima CE, Silva AMB (1999) Methodology for the implementation of the energy efficiency program for the industrial sector in Brazil proceedings ACEEE summer study on energy efficiency in industry, pp 761-770

Demirbas A (2009) Progress and recent trends in biodiesel fuels. Energy Convers Manag 50:14-34

Demirbas ADMF (2010) Algae energy: algae as a new source of biodiesel. Green energy and technology. Springer, Berlin. https://doi. org/10.1007/978-1-84996-050-2 
Edwards R, Mahieu V, Rouveirolles P (2007) Well-to-wheels analysis of future automotive fuels and powertrains in the European context

Energy Commission ST (2013) Peninsular Malaysia electricity supply industry outlook, Putrajaya

Energy Commission ST (2014) Peninsular Malaysia electricity supply industry outlook. Putrajaya, Malaysia

Hsu DA (2014) 2014 Environmental performance index, full report and analysis, Yale

Institute WC (2007) Coal meeting the climate challenge: technology to reduce greenhouse gas emissions. Richmond, UK

Kabir E, Kumar P, Kumar S, Adelodun AA, Kim K-H (2018) Solar energy: potential and future prospects. Renew Sustain Energy Rev 82:894-900. https://doi.org/10.1016/j.rser.2017.09.094

Kentucky Uo (2012)

Mahlia TMI, Masjuki HH, Choudhury IA (2002) Theory of energy efficiency standards and labels. Energy Convers Manag 43:743-761. https://doi.org/10.1016/s0196-8904(01)00073-5

Malaysia GSaSDE (2006) Statistics of piped gas industry

Manjinder Bajwa PG (2011) Comparing the thermal power plant performance at various output loads by energy auditing (a statistical analyzing tool). Int J Mech Eng Technol 2:111-126

Manzano-Agugliaro F, Taher M, Zapata-Sierra A, Juaidi A, Montoya FG (2017) An overview of research and energy evolution for small hydropower in Europe. Renew Sustain Energy Rev 75:476-489. https://doi.org/10.1016/j.rser.2016.11.013

Mardoyan A, Braun P (2015) Analysis of Czech subsidies for solid biofuels. Int J Green Energy 12:405-408

Maroušek J, Zeman R, Vaníčková R, Hašková S (2014) New concept of urban green management. Clean Technol Environ Policy 16:1835-1838

Nag P (2008) Low load operational flexibility for siemens G class gas turbines. Orlando, Florida

NRDC Summary of EPA's Clean Power Plan (2014) Carbon pollution standards for existing power plants
Office AG (2000a) Efficiency standard for power generation working group

Office AG (2000b) Generator efficiency standards

Office AG (2001) Generator efficiency standard V1.2 technical guidelines $\mathrm{p} 24$

Pandey T (2014) Depleting reserve margins push M'sia to import power

Pioro I, Duffey R (2015) Nuclear power as a basis for future electricity generation. J Nucl Eng Radiat Sci 1:011001-011019. https://doi. org/10.1115/1.4029420

Pioro IL, Duffey RB, Kirillov PL, Panchal R (2016) Introduction: a survey of the status of electricity generation in the world. In: Pioro IL (ed) Handbook of generation IV nuclear reactors. Woodhead Publishing, Cambridge, pp 1-34. https://doi.org/10.1016/ B978-0-08-100149-3.00001-X

Rahman KA, Yusof MZM, Salleh MNM, Leman AM (2015) Implementation of energy efficiency standards and labelling for household electrical appliances: a comparison among Asian countries vol 45. https://doi.org/10.3303/cet1545278

Ranganathan J (2004) The greenhouse gas protocol: a corporate accounting and reporting standard

Saidur R, Mahlia TMI (2010) Energy, economic and environmental benefits of using high-efficiency motors to replace standard motors for the Malaysian industries. Energy Policy 38:4617-4625. https://doi.org/10.1016/j.enpol.2010.04.017

Slatick BDHaER (1994) Carbon dioxide emission factors for Coal United States Energy Information Administration, pp 1-8

Staffell I (2011) The energy and fuel data Sheet university of Birmingham, vol 1, p 11

World Energy Resources (2016) World energy council

Zerrahn A (2017) Wind power and externalities. Ecol Econ 141:245260. https://doi.org/10.1016/j.ecolecon.2017.02.016 